\title{
Las ordenanzas locales como instrumento de exclusión social: la regulación que afecta a las personas sin hogar es derecho administrativo del enemigo ${ }^{1}$
}

\section{Local ordinances as an instrument of social exclusion: the regulation affecting the homeless is administrative law of the enemy}

\author{
Eduardo Melero Alonso \\ Universidad Autónoma de Madrid \\ eduardo.melero@uam.es
}

\begin{abstract}
RESUMEN
En este trabajo se analizan las ordenanzas locales, en especial las denominadas ordenanzas de convivencia, en la medida en que afectan a las actividades cotidianas de las personas sin hogar. Son tres los ámbitos de regulación: la prohibición de la mendicidad; la prohibición de dormir, lavarse y realizar las necesidades fisiológicas en espacios públicos; y la prohibición de rebuscar en la basura. Esta regulación se somete a un análisis crítico, centrado en el hecho de que incide en los derechos fundamentales de las personas sin hogar. Los parámetros básicos de control son la reserva de ley y, sobre todo, el principio de proporcionalidad. La conclusión a la que se llega es que, en muchos supuestos, esta regulación no sólo es ilegal, también se puede incluir dentro de la categoría derecho administrativo del enemigo.
\end{abstract}

\section{Palabras clave}

Ordenanzas locales. Ordenanzas de convivencia. Personas sin hogar. Exclusión social. Derecho administrativo del enemigo.

\begin{abstract}
This paper discusses local ordinances, especially the so-called coexistence ordinances, to the extent they affect the daily activities of the homeless. There are three areas of regulation: the prohibition of begging; a ban on sleeping, washing and perform physiological needs in public spaces; and the prohibition of sorting through garbage. This regulation is subjected to a critical analysis, focusing on the fact that has an impact on the fundamental rights of the homeless. The basic parameters of control are the reserve of law and, above all, the principle of proportionality. The conclusion reached is that, in many cases, this regulation is not only illegal, it can also be included within the category Administrative Law of the enemy.
\end{abstract}

\section{Keywords}

Local ordinances. Coexistence ordinances. Homeless. Social exclusion. Administrative Law of the enemy.

1 Este trabajo tiene su origen en mi intervención en el Seminario «Parches de hierro para un sistema que se desmorona. Reformas en nuestro sistema punitivo. Estado de excepción permanente», organizado por la Asociación Libre de Abogados, los días 11 y 12 de junio de 2015, en la mesa dedicada a criminalización de la pobreza. 
REALA. Nueva Época - N. ${ }^{6}$, noviembre 2016 - ISSN: 1989-8975 - DOI: 10.24965/reala.v0i6.10384 - [Págs. 7-26]

Las ordenanzas locales como instrumento de exclusión social: la regulación que afecta a las personas sin hogar es derecho ...

Eduardo Melero Alonso

\section{SUMARIO}

1. INTRODUCCIÓN. 2. LA EXPANSIÓN DEL PODER SANCIONADOR LOCAL. 3. LAS ORDENANZAS DE CONVIVENCIA Y LAS PERSONAS SIN HOGAR. 3.1. Regulación de la mendicidad. 3.2. Regulación que incide en las actividades cotidianas de las personas sin hogar. 4. LA PROHIBICIÓN DE REBUSCAR EN LA BASURA EN LAS ORDENANZAS DE CONVIVENCIA Y EN LAS ORDENANZAS DE LIMPIEZA. 5. ANÁLISIS CRÍTICO DE LAS ORDENANZAS LOCALES EN RELACIÓN CON LAS PERSONAS SIN HOGAR. 5.1. Competencia de los municipios para dictar estas ordenanzas. 5.2. Sanciones no pecuniarias previstas en las ordenanzas. 5.3. Derechos de las personas sin hogar implicados: análisis del libre desarrollo de la personalidad, la libertad de expresión y el derecho a la libertad personal. 5.4. Parámetros de control de las ordenanzas que inciden en los derechos de las personas sin hogar. 5.4.1. Reserva de ley en materia de derechos fundamentales. 5.4.2. Principio de proporcionalidad y ordenanzas locales que afectan a las personas sin hogar. 5.4.3. Ponderación entre los derechos de las personas sin hogar y los derechos y bienes jurídicos protegidos por las ordenanzas. 5.4.3.1. Ponderación entre mendicidad y libertad de expresión. 5.4.3.2. Derecho a la libertad personal y prohibición de dormir en la calle. 6. LA REGULACIÓN SOBRE LAS PERSONAS SIN HOGAR EN LAS ORDENANZAS LOCALES COMO DERECHO ADMINISTRATIVO DEL ENEMIGO. 7. CONCLUSIONES Y PERSPECTIVAS. 8. BIBLIOGRAFÍA CITADA.

\section{INTRODUCCIÓN}

En este trabajo analizo de qué manera las ordenanzas locales inciden en la vida diaria de las personas sin hogar. La cuestión de fondo es si las ordenanzas tratan a estas personas como individuos sin derechos o con derechos reducidos. Para ello voy a analizar, fundamentalmente, las ordenanzas de convivencia señalando alguna cuestión regulada también en las ordenanzas de limpieza.

$\mathrm{Mi}$ análisis se limita al derecho normado, al contenido de las ordenanzas. No tengo elementos para valorar el derecho practicado, es decir, cómo se están aplicando estas ordenanzas por la policía local. Un estudio completo debería tener en cuenta ambas dimensiones del derecho.

El primer problema que se plantea es la dificultad de la definición del concepto de persona sin hogar. En este sentido, me parece útil la propuesta formulada por FEANTSA (Federación Europea de Organizaciones Nacionales que trabajan con Personas sin Hogar) que distingue cuatro categorías, no ordenadas jerárquicamente: a) Sin techo, b) Sin vivienda, c) Vivienda Insegura, y d) Vivienda Inadecuada. Esta clasificación se basa en la distinción de tres ámbitos que afectan al hogar, en el que la ausencia de uno de ellos puede dar lugar a una situación de sin hogar. Se trata de: 1) el ámbito físico: tener un espacio o una vivienda adecuada para vivir, 2) el ámbito social: poder salvaguardar la intimidad y disfrutar de las relaciones sociales, y 3) tener el derecho legal de ocupar una vivienda ${ }^{2}$. La definición de persona sin hogar que asume FEANTSA es: «toda persona que no puede acceder o conservar un alojamiento adecuado, adaptado a su situación personal, permanente y que proporcione un marco estable de convivencia, ya sea por falta de recursos económicos, ya sea por tener dificultades personales o sociales para llevar una vida autónoma» ${ }^{3}$.

El cuanto a la estructura, el trabajo comienza con el análisis del marco jurídico al que se someten las ordenanzas locales sancionadoras. Para pasar a analizar el contenido de las ordenanzas en lo que afecta a la vida cotidiana de las personas sin hogar. Se analizarán los principales problemas jurídicos que plantean, especialmente, el hecho de que inciden en los derechos de las personas sin hogar. Por último, llevaré a cabo un análisis crítico del modelo de convivencia que implican, de la política que hay detrás, tomando como herramienta de análisis el derecho administrativo del enemigo.

\section{LA EXPANSIÓN DEL PODER SANCIONADOR LOCAL}

La reserva de ley en materia sancionadora (artículo $25 \mathrm{CE}$ ), al exigir que una norma con rango de ley delimite las infracciones y sanciones, ha supuesto tradicionalmente un importante límite a la regulación a través de ordenanzas locales ${ }^{4}$.

\footnotetext{
2 PONCE SOLÉ, Juli y FERNÁNDEZ EVANGELISTA, Guillem (2010): 44

3 Véase PONCE SOLÉ, Juli y FERNÁNDEZ EVANGELISTA, Guillem (2010): 66-67.

4 Véase PEMÁN GAVÍN, Juan M. ${ }^{a}$ (2007): 19-23 y ORDUÑA PRADA, Enrique (2016): 29-32.
} 
Doctrinalmente se propuso la flexibilización de esta reserva de ley en relación con las ordenanzas locales, basándose en la legitimación democrática directa del Pleno del Ayuntamiento, en la función que la reserva de ley cumple en la actualidad, y en la importancia de la reserva de ley para la distribución territorial del poder $^{5}$. Flexibilización que fue reconocida por el Tribunal Constitucional, en primer lugar, en el ámbito tributario (STC 233/1999, de 16 de diciembre, FJ 10) y, posteriormente, en materia sancionadora (STC 132/2001).

La STC 132/2001, de 8 de junio, FJ 3, parte de un concepto amplio de sanción en el que se incluye cualquier «decisión administrativa con finalidad represiva, limitativa de derechos, basada en una previa valoración negativa de la conducta del titular de la licencia a la luz de lo dispuesto en la ordenanza municipal» ${ }^{6}$. Junto a la amplitud material del contenido de la reserva en materia sancionadora, flexibiliza la intensidad de la regulación legal necesaria para cumplir las exigencias del artículo $25.1 \mathrm{CE}$.

Para el TC, «la exigencia de ley para la tipificación de infracciones y sanciones ha de ser flexible en materias donde, por estar presente el interés local, existe un amplio campo para la regulación municipal y siempre que la regulación local la apruebe el Pleno del Ayuntamiento» ${ }^{7}$. Esta flexibilización se basa en que las ordenanzas locales son aprobadas por un órgano representativo [artículo 22.2.d) LRBRL] y en la garantía constitucional de la autonomía local (artículos 137 y $140 \mathrm{CE})^{8}$.

La flexibilización de la intensidad de la regulación legal se concreta en dos exigencias mínimas. En cuanto a la delimitación de las infracciones, «corresponde a la ley la fijación de los criterios mínimos de antijuridicidad conforme a los cuales cada Ayuntamiento puede establecer tipos de infracciones»; en el sentido de que deben fijarse legalmente los «criterios que orienten y condicionen» la regulación municipal, sin que sea necesario la definición de tipos ni la fijación de tipos genéricos de infracciones que luego serían completados por las ordenanzas. Es decir, las ordenanzas «pueden definir directamente los tipos de infracción» en el marco de los criterios legalmente establecidos ${ }^{9}$. En cuanto a las sanciones, la ley ha de establecer «las clases de sanciones que pueden establecer las ordenanzas municipales», siendo suficiente con que se recoja «una relación de las posibles sanciones que cada Ordenanza Municipal puede predeterminar» ${ }^{10}$.

Esta doctrina constitucional se plasmó en 2013, con la modificación de la Ley 7/1985, de 2 de abril, Reguladora de las Bases del Régimen Local (LRBRL). La Ley 57/2003, de 16 de diciembre, de medidas para la modernización del gobierno local, introdujo el nuevo Título XI «Tipificación de las infracciones y sanciones por las entidades locales en determinadas materias» en la LRBRL (artículos 139 a 141) ${ }^{11}$. No se establecen sanciones concretas, sino que se permite que las ordenanzas locales, cuando no exista legislación sectorial específica, tipifiquen infracciones y sanciones «por el incumplimiento de deberes, prohibiciones o limitaciones contenidos en las correspondientes ordenanzas» (artículo 139). Las materias a las que se refiere este precepto son: «ordenación de las relaciones de convivencia de interés local y del uso de sus servicios, equipamientos, infraestructuras, instalaciones y espacios públicos». El artículo 140 clasifica las infracciones a las ordenanzas locales en muy graves, graves y leves; establece seis infracciones genéricas muy graves ${ }^{12}$; y determina los criterios para clasificar las infracciones en graves y leves ${ }^{13}$. Por último, el artículo 141 fija los límites de las sanciones económicas: infracciones muy graves hasta 3.000 euros, infracciones graves hasta 1.500 euros, e infracciones leves hasta 750 euros.

Esta flexibilización de la reserva de ley en materia sancionadora ha reforzado las posibilidades de actuación de los municipios, actuando como un elemento clave en la potenciación de su potestad normativa ${ }^{14}$.

5 Véase VELASCO CABALLERO, Francisco (2009): 255-257.

${ }^{6}$ STC 132/2001, de 8 de junio, FJ 3. A juicio de VELASCO CABALLERO, Francisco(2009): 262, sólo quedan fuera de la reserva de ley delimitada por el TC las medidas cautelares y las multas coercitivas.

7 STC 132/2001, de 8 de junio, FJ 6.

8 STC 132/2001, de 8 de junio, FJ 5.

9 VELASCO CABALLERO, Francisco (2009): 264.

10 STC 132/2001, de 8 de junio, FJ 6.

11 También se modificó el artículo 127.1 de la Ley 30/1992, de 26 de noviembre, de Régimen Jurídico de las Administraciones Públicas y del Procedimiento Administrativo Común, para incluir una referencia expresa al Título XI LRBRL.

12 En relación con este trabajo deben destacarse dos: 1) «Una perturbación relevante de la convivencia que afecte de manera grave, inmediata y directa a la tranquilidad o al ejercicio de derechos legítimos de otras personas, al normal desarrollo de actividades de toda clase conformes con la normativa aplicable o a la salubridad u ornato públicos», siempre que se trate de conductas que no estén previstas en la legislación de seguridad ciudadana [artículo 140.1.a)]; y 2) «Los actos de deterioro grave y relevante de espacios públicos o de cualquiera de sus instalaciones y elementos, sean muebles o inmuebles, no derivados de alteraciones de la seguridad ciudadana» [artículo 140.1.f)].

13 VELASCO CABALLERO, Francisco (2009): 273-274, señala que el artículo 140 LRBRL debe ser completado con los criterios mínimos de antijuridicidad que establezcan las leyes sectoriales estatales o autonómicas para cumplir las exigencias de la reserva de ley.

14 MERINO ESTRADA, Valentín (2006): 491; ORTEGA BERNARDO, Julia (2014): 52. 
REALA. Nueva Época - N. ${ }^{6}$, noviembre 2016 - ISSN: 1989-8975 - DOI: 10.24965/reala.v0i6.10384 - [Págs. 7-26]

Las ordenanzas locales como instrumento de exclusión social: la regulación que afecta a las personas sin hogar es derecho ...

Eduardo Melero Alonso

Éste sería uno de los factores que explican la expansión de la regulación local en materia de convivencia, junto a la retirada del legislador estatal de las materias relacionadas con el civismo y la existencia de una problemática real sobre esta cuestión ${ }^{15}$.

\section{LAS ORDENANZAS DE CONVIVENCIA Y LAS PERSONAS SIN HOGAR}

Uno de los ámbitos destacados en los que se ha puesto de manifiesto esta intensificación de la potestad normativa local ha sido el de las ordenanzas de convivencia. Que ha dado lugar a la puesta en práctica de una «verdadera política de civismo» ${ }^{16}$. Estas Ordenanzas, debido a las múltiples prohibiciones e infracciones que recogen, han supuesto «un renovado impulso a la potestad sancionadora de los Ayuntamientos» ${ }^{17}$.

En esta política municipal de civismo han ejercido una gran influencia, tanto la «Ordenanza de medidas para fomentar y garantizar la convivencia ciudadana en el espacio público de Barcelona», de 23 de diciembre de $2005^{18}$, reconocido por la doctrina ${ }^{19}$, como la «Ordenanza tipo de seguridad y convivencia ciudadana», elaborada por la Federación Española de Municipios y Provincias (FEMP) ${ }^{20}$. Ambas se han convertido en un instrumento para la uniformización de la regulación local en esta materia, como se pone de manifiesto con una búsqueda aleatoria en internet.

Estas dos ordenanzas, en la regulación que afecta a las personas sin hogar, han servido como modelo, del que muchos municipios han tomado aquellos elementos que han considerado oportunos. Sin ánimo de un análisis exhaustivo, esa influencia se manifiesta en las ordenanzas de San Sebastián de los Reyes ${ }^{21}$, Sevilla ${ }^{22}$, Illescas ${ }^{23}$, Granada ${ }^{24}$, Lorca ${ }^{25}$, Alcalá de Henares ${ }^{26}$, Irún ${ }^{27}$, Segovia ${ }^{28}$, El Puerto de Santa María ${ }^{29}$, Capdepera $^{30}$, o San Cristóbal de La Laguna ${ }^{31}$.

15 PEMÁN GAVÍN, Juan M. ${ }^{a}$ (2010): 16-18. Más detallado en PEMÁN GAVÍN, Juan Mª (2007): 12-28.

16 PEMÁN GAVÍN, Juan M. a (2010): 19.

17 CASINO RUBIO, Miguel (2011): 755, para quien la novedad relevante que plantean estas ordenanzas es «la lucha sin cuartel y a golpe de sanción que anuncian contra la falta de civismo de los ciudadanos».

18 Publicada en el Boletín Oficial de la Provincia de Barcelona de 24 de enero de 2006.

19 PEMÁN GAVÍN, Juan M. ${ }^{a}$ (2007): 53; PEMÁN GAVÍN, Juan M. ${ }^{a}$ (2010): 20; y CASINO RUBIO, Miguel (2011): 745.

20 Puede consultarse en la página web de la FEMP (www.femp.es), en el apartado Accesos directos, Ordenanzas FEMP.

21 «Ordenanza municipal para la protección de la convivencia ciudadana y prevención de actuaciones antisociales» de San Sebastián de los Reyes, de 21 de febrero de 2008, Boletín Oficial de la Comunidad de Madrid de 2 de junio (regula el uso impropio del espacio público, prohíbe realizar necesidades fisiológicas y rebuscar en la basura, no establece nada en relación con la mendicidad).

22 «Ordenanza Municipal de Medidas para el Fomento y Garantía de la Convivencia Ciudadana en los Espacios Públicos de Sevilla», de 20 de junio de 2008, Boletín Oficial de la Provincia de Sevilla de 18 de julio (prohíbe la mendicidad y realizar necesidades fisiológicas en los espacios públicos; considera que es coactivo el ofrecimiento de aparcamiento).

${ }^{23}$ «Ordenanza de Medidas para Fomentar y Garantizar la Convivencia Ciudadana en el Espacio Público de Illescas», de 16 de julio de 2009, Boletín Oficial de la Provincia de Toledo de 8 de Octubre (prohíbe la mendicidad, el uso impropio del espacio público y realizar las necesidades fisiológicas en espacios públicos).

24 "Ordenanza de medidas para fomentar y garantizar la convivencia ciudadana en el espacio público de Granada», de 25 de septiembre de 2009, Boletín Oficial de la Provincia de Granada de 21 de octubre (prohíbe la mendicidad, el uso impropio del espacio público y la realización de necesidades fisiológicas).

${ }_{25}$ «Ordenanza Municipal sobre Protección de la Convivencia Ciudadana y Prevención de Actuaciones Antisociales» de Lorca, de 22 de febrero de 2010, Boletín Oficial de la Región de Murcia de 5 de abril de 2010 (prohíbe la mendicidad, el uso impropio del espacio público -aunque no prohíbe dormir en la calle- y la realización de las necesidades fisiológicas).

${ }^{26}$ «Ordenanza municipal para fomentar y garantizar la convivencia ciudadana en el espacio público de Alcalá de Henares», de 21 de septiembre de 2010, Boletín Oficial de la Comunidad de Madrid de 19 de octubre (prohíbe la mendicidad, el uso impropio del espacio público y realizar las necesidades fisiológicas).

27 «Ordenanza Municipal sobre Comportamiento cívico y reguladora del uso, ocupación y limpieza de la vía pública», de Irún, de 30 de marzo de 2011, Boletín Oficial de Gipuzkoa de 15 de abril (prohíbe la mendicidad y rebuscar en la basura).

28 «Ordenanza de convivencia ciudadana del Ayuntamiento de Segovia 2011», Boletín Oficial de la Provincia de Segovia de 20 de abril (prohíbe la mendicidad, el uso impropio del espacio público y realizar las necesidades fisiológicas).

29 «Ordenanza Municipal de Medidas para fomentar y garantizar la Convivencia Ciudadana en el espacio público de El Puerto de Santa María», de 8 de marzo de 2012, Boletín Oficial de la Provincia de Cádiz de 4 de mayo (prohíbe la mendicidad, el uso impropio del espacio público y realizar las necesidades fisiológicas).

30 "Ordenanza de medidas para fomentar y garantizar la convivencia ciudadana en el espacio público de Capdepera», Boletín Oficial de las Islas Baleares de 9 de abril de 2016 (prohíbe la mendicidad, el uso impropio del espacio público y realizar las necesidades fisiológicas).

${ }^{31}$ «Ordenanza de Convivencia Ciudadana de San Cristóbal de la Laguna», de 10 de marzo de 2016; Boletín Oficial de la Provincia de Santa Cruz de Tenerife de 20 de mayo (prohíbe la mendicidad, el uso impropio del espacio público y realizar las necesidades fisiológicas). 
Tanto la Ordenanza de convivencia de Barcelona como la Ordenanza tipo de la FEMP recogen un contenido muy amplio ${ }^{32}$ : están compuestas por 102 y 182 artículos respectivamente. E incluyen múltiples materias. Así, la Ordenanza tipo de la FEMP regula, además de unos principios generales de convivencia, las siguientes cuestiones: la limpieza de edificios, mobiliario urbano y la vía pública; atentados contra la dignidad de las personas; la degradación visual del entorno urbano con pintadas, pancartas, octavillas, ...; la realización de apuestas en la vía pública; el uso inadecuado del espacio público para juegos; la mendicidad; la utilización del espacio público para el ofrecimiento y demanda de servicios sexuales; la realización de necesidades fisiológicas en espacios públicos; el consumo de bebidas alcohólicas; el comercio ambulante no autorizado; la prestación de servicios no autorizados, el uso impropio del espacio público; las actividades vandálicas; la contaminación acústica y normas básicas de cuidado de la vía pública. Ello pone de manifiesto tanto el carácter «transversal» de estas ordenanzas ${ }^{33}$, como su marcada vocación reglamentista ${ }^{34}$.

Según la exposición de motivos de la Ordenanza tipo FEMP (muy similar en la Ordenanza de Barcelona): «Es objetivo primordial de esta Ordenanza preservar el espacio público como un lugar de encuentro, convivencia y civismo, en el que todas las personas puedan desarrollar en libertad sus actividades de libre circulación, ocio y recreo, con pleno respeto a la dignidad y a los derechos de los demás y a la pluralidad de expresiones y de formas de vida diversas» (véase también el artículo 1).

En este trabajo partiré de la regulación contenida en la Ordenanza de convivencia de Barcelona y en la Ordenanza tipo de la FEMP, que mantienen una regulación prácticamente idéntica en lo que afecta a las personas sin hogar. En ambas ordenanzas se señalan expresamente cuáles son los fundamentos en que se basa la regulación ${ }^{35}$. Por tanto, se hace transparente la ideología que hay detrás de la normativa y el modelo de convivencia que se plantea.

\subsection{Regulación de la mendicidad}

Esta cuestión se encuentra regulada dentro de una sección denominada «Ocupación del espacio público por conductas que adoptan formas de mendicidad», dentro de un capítulo destinado a regular "Otras conductas en el espacio público» (artículos 34 a 37 Ordenanza de Barcelona; artículos 58 a 61 Ordenanza FEMP).

Se establecen cuatro prohibiciones y un tratamiento diferenciado para la denominada mendicidad con «raíz social» (artículos 35 y 36 Ordenanza de Barcelona, artículos 59 y 60 Ordenanza FEMP):

1. En primer lugar, se prohíben «aquellas conductas que, bajo la apariencia de mendicidad o bajo formas organizadas, representen actitudes coactivas o de acoso, u obstaculicen e impidan intencionadamente el libre tránsito de los ciudadanos y ciudadanas por los espacios públicos» (art. 35.1 Ordenanza Barcelona, art. 59.1 Ordenanza FEMP). La realización de estas conductas tiene la consideración de infracción leve, pudiendo ser sancionada con multa de hasta 120 euros, salvo que los hechos supongan la comisión de una infracción más grave (art. 36.2 Ordenanza Barcelona; art. 60.2 Ordenanza FEMP).

En alguna ordenanza se mantiene una comprensión amplia de las formas coactivas de mendicidad. Así, la Ordenanza Municipal de Medidas para el Fomento y Garantía de la Convivencia Ciudadana en los Espacios Públicos de Sevilla, de 20 de junio de 2008, establece en su artículo 32.3: «El ofrecimiento de lugar para aparcamiento en el espacio público a los conductores de vehículos con la intención de la obtención de un beneficio económico por personas no autorizadas, será considerado en todo caso forma coactiva de mendicidad» ${ }^{36}$.

32 Ésta es una característica general de las ordenanzas de convivencia según MERINO ESTRADA, Valentín (2006): 497, con más detalle en ORDUÑA PRADA, Enrique (2016): 288 y ss.

${ }_{33}$ Así, la Ordenanza de convivencia de Barcelona, señala expresamente en su exposición de motivos que tiene «una naturaleza claramente transversal, al afectar a un buen número de competencias locales y atravesar literalmente gran parte de la estructura de responsabilidades políticas y del sistema administrativo municipal».

${ }^{34}$ Como afirma CASINO RUBIO, Miguel (2011): 754, estas ordenanzas dan «la impresión de que los Ayuntamientos han decidido ordenar la vida ciudadana hasta en sus últimos detalles».

${ }^{35}$ En relación con esta cuestión PEMÁN GAVÍN, Juan M. ${ }^{a}$ (2010): 21, señala que "La política municipal de civismo se sustenta en un discurso en gran medida nuevo en el tono y en los contenidos. Un discurso que hace un importante esfuerzo pedagógico en torno al civismo y a la calidad de vida de la ciudad y, en particular, intenta explicitar las razones que justifican las prohibiciones, con una visión positiva de las cosas que pone de relieve los beneficios que derivan para la comunidad de las regulaciones y actuaciones en torno a la materia. Así, se pone énfasis en los fundamentos de las medidas restrictivas que incorporan las Ordenanzas mediante la identificación de los valores o bienes jurídicos involucrados y de los derechos que se protegen en cada aspecto regulado: no sólo se prohíben conductas; sino que también se reconocen derechos».

${ }^{36}$ Regulación que se reitera en el artículo 24.2 de la Ordenanza de Medidas para Fomentar y Garantizar la Convivencia Ciudadana en el Espacio Público de Illescas, de 16 de julio de 2009. 
Resulta llamativo que las ordenanzas no mencionen el Código Penal en lo relativo a las «actitudes coactivas o de acoso», como sí ocurre en el caso de la mendicidad ejercida por menores o por personas con discapacidad. El tipo básico de coacciones establecido en el artículo 172.1 del Código Penal consiste en impedir a otra persona con violencia hacer lo que la ley no prohíbe, o en compelirle a efectuar lo que no quiere, sea justo o injusto; siempre que no esté legítimamente autorizado a ello. En el tipo básico de coacciones es fundamental el empleo de violencia, que se ha ido espiritualizando de manera que no sólo incluye el empleo de la fuerza física contra una persona sino que también incluye la intimidación con causarle un mal inmediato, entre otras ${ }^{37}$. De esta forma sólo se incurrirá en delito de amenazas (artículos 169 a 171 del Código Penal) cuando la intimidación se refiera a un mal futuro, no inmediato ${ }^{38}$.

2. En segundo lugar, se prohíbe «el ofrecimiento de cualquier bien o servicio a personas que se encuentren en el interior de vehículos privados o públicos»; incluyendo expresamente «la limpieza de los parabrisas de los automóviles detenidos en los semáforos o en la vía pública así como el ofrecimiento de cualquier objeto» (art. 35.2 Ordenanza Barcelona; art. 59.2 Ordenanza FEMP). Queda prohibido así, el ofrecimiento de pañuelos de papel, la prestación de servicios de aparcamiento, e incluso la realización de espectáculos artísticos. Con carácter general, se considera infracción leve, sancionada con multa de hasta 120 euros. Salvo en el supuesto de «limpieza de los parabrisas de los automóviles detenidos en los semáforos o en la vía pública», que se considera infracción grave, sancionada con una multa de 750,01 euros hasta 1.500 euros (art. 36.3 Ordenanza Barcelona; art 60.3 Ordenanza FEMP) ${ }^{39}$.

3. También «queda totalmente prohibida la mendicidad ejercida por menores o aquella que se realice, directa o indirectamente, con menores o personas con discapacidades», sin perjuicio de lo que establece el artículo 232 del Código Penal (art. 35.3 Ordenanza Barcelona; art. 59.3 Ordenanza FEMP). La mendicidad «ejercida, directa o indirectamente, con acompañamiento de menores o con personas con discapacidad» se considera infracción muy grave, sancionada con multa de 1.500,01 a 3.000 euros; sin perjuicio de lo previsto en el artículo 232.1 del Código Penal (art. 36.4 Ordenanza Barcelona; art. 60.4 Ordenanza FEMP). También se prevé que «Si la mendicidad es ejercida por menores, las autoridades municipales prestarán a éstos, de forma inmediata, la atención que sea precisa, sin perjuicio de que se adopte el resto de las medidas que prevé, en su caso, el ordenamiento jurídico» ${ }^{40}$.

El delito de utilización de menores o personas con discapacidad para la mendicidad se regula en el artículo 232 de la Ley Orgánica 10/1995, de 23 de noviembre, del Código Penal. El tipo básico del artículo 232.1 consiste en utilizar o prestar a menores de edad o personas con discapacidad necesitadas de especial protección para la práctica de la mendicidad, incluso aunque ésta se realice de forma encubierta ${ }^{41}$. Conducta castigada con pena de prisión de seis meses a un año. Para la STS de 10 de noviembre de 2000 (Sala de lo Penal, núm. 1731/2000), FJ único, la aplicación del artículo 232.1 se limita «a aquellos supuestos en los que son los menores o incapaces los que solicitan la limosna, aunque sea de modo encubierto»; sin incluir «la conducta de aquellas personas que se hagan acompañar de menores para practicar la mendicidad $»^{42}$. Por su parte, el

${ }^{37}$ Véase RAGUÉS I VALLĖS, Ramon (2015): 110-111. En el mismo sentido, MUÑOZ CONDE, Francisco (2015): 140.

38 RAGUÉS I VALLÈS, Ramon (2015): 104.

${ }^{39}$ En este caso no se exige previa orden de abandono de la actividad y se procede al inicio del procedimiento administrativo sancionador.

40 La «Ordenanza Municipal de Convivencia Ciudadana de Oviedo», de 17 de mayo de 2015 (Boletín Oficial del Principado de Asturias de 14 de junio de 2010), sigue, en gran medida, este modelo de regulación. Me parece interesante destacar dos cuestiones, que ponen de manifiesto el exceso reglamentista en que se incurre:

[1] Se establece expresamente que «No se considera mendicidad las cuestaciones organizadas por entidades o asociaciones legalmente constituidas» (art. 11.2). Con el fin de evitar que se aplique la definición de mendicidad contenida previamente en dicho artículo 11.2: «Cualquier solicitud de donativo o limosna ejercida por menores o incapaces, así como la ejercida bajo formas o redes organizadas siempre que no sea subsumible en las conductas tipificadas penalmente».

[2] También se señala expresamente que «No se considera mendicidad prohibida por esta Ordenanza las actividades musicales, artísticas y de animación de calle ejercidas en la vía pública de forma puntual, no periódica siempre que se solicite la dádiva de forma no coactiva y como contraprestación a la actuación realizada» (art. 11.4). Para evitar que se entiendan incluidas en la conducta considerada como mendicidad en dicho precepto: «El ofrecimiento o prestación de servicios en la vía pública no requeridos a cambio de un donativo o precio, tales como la limpieza de parabrisas de vehículos, aparcamiento y vigilancia de coches en la vía pública».

41 Según MUÑOZ CONDE, Francisco (2015): 290, el bien jurídico protegido en el tipo básico del artículo 232.1 es la dignidad humana; no se castiga la mendicidad sino que lo que pretende evitar es la instrumentalización de menores o personas con discapacidad necesitadas de especial protección con el fin de obtener un beneficio económico. Para CASTIÑEIRA PALOU, M. ${ }^{a}$ Teresa y MONTANER FERNÁNDEZ, Raquel (2015): 221, el bien protegido es la seguridad de la víctima vinculado con su dignidad. 221-222.

${ }^{42}$ Doctrina que han seguido las audiencias, véase CASTIÑEIRA PALOU, M. ${ }^{a}$ Teresa y MONTANER FERNÁNDEZ, Raquel (2015): 
REALA. Nueva Época - N. ${ }^{\circ}$ 6, noviembre 2016 - ISSN: 1989-8975 - DOI: 10.24965/reala.v0i6.10384 - [Págs. 7-26]

Las ordenanzas locales como instrumento de exclusión social: la regulación que afecta a las personas sin hogar es derecho ..

Eduardo Melero Alonso

artículo 232.2 establece un tipo cualificado que abarca tres conductas: traficar con menores o personas con discapacidad necesitadas de especial protección, utilizar con ellos violencia o intimidación, o suministrarles sustancias perjudiciales para la salud; siempre que estas conductas se realicen con el fin de utilizar a estas personas para la práctica de la mendicidad ${ }^{43}$. Este tipo agravado implica una pena de prisión de uno a cuatro años.

A través de estas ordenanzas se puede sancionar el comportamiento de «hacerse acompañar de menores de edad o personas con discapacidad necesitadas de especial protección» ${ }^{44}$; comportamiento que puede considerarse incluido dentro de la mendicidad realizada con menores o personas con discapacidad.

4. Además, se prohíbe «la realización en el espacio público de actividades de cualquier tipo cuando obstruyan o puedan obstruir el tráfico rodado por la vía pública, pongan en peligro la seguridad de las personas o impidan de manera manifiesta el libre tránsito de las personas por aceras, plazas, avenidas, pasajes y bulevares u otros espacios públicos. Estas conductas están especialmente prohibidas cuando se desarrollen en la calzada, en los semáforos o invadiendo espacios de tráfico rodado» (art. 35.4 Ordenanza Barcelona; art. 59.4 Ordenanza FEMP). Este precepto podría aplicarse en el caso de espectáculos artísticos callejeros, realizados con intención de obtener una dádiva, en los que se produce una gran afluencia de personas. Con carácter general, estas conductas tienen la consideración de infracciones leves, sancionadas con multa de hasta 200 euros; en el caso de las conductas calificadas como especialmente prohibidas, la sanción puede llegar a 300 euros (art. 36.5 Ordenanza Barcelona; art. 60.5 Ordenanza FEMP).

5. Por último, se regulan las formas de mendicidad «que tengan raíz social» (art. 35.5 Ordenanza Barcelona; art. 59.5 Ordenanza FEMP). Han de tratarse de formas de mendicidad no previstas en los supuestos anteriores. En este caso se establece que los agentes de la autoridad, de acuerdo únicamente con el Plan de Inclusión Social del municipio, contactarán con los servicios sociales «al efecto de que sean éstos los que conduzcan a aquellas personas que las ejerzan a los servicios sociales de atención primaria, con la finalidad de asistirlas, si fuera necesario».

Todas estas infracciones se justifican en la Ordenanza tipo en la protección de determinados bienes y derechos que se pretenden salvaguardar (art. 58 Ordenanza FEMP, denominado «Fundamentos de la regulación»). Se trata de «el derecho que tienen los ciudadanos y ciudadanas a transitar por el Municipio [...] sin ser molestados o perturbados en su voluntad, la libre circulación de las personas, la protección de menores, así como el correcto uso de las vías y los espacios públicos» (art. 34.1 Ordenanza Barcelona; art. 58.1 Ordenanza FEMP). Y, en especial, se trata de proteger a las personas «frente a conductas que adoptan formas de mendicidad insistente, intrusiva o agresiva, así como organizada [...] así como frente a cualquier otra forma de mendicidad que, directa o indirectamente, utilice a menores como reclamo o éstos acompañen a la persona que ejerce esta actividad» (art. 34.2 Ordenanza Barcelona; art. 58.2 Ordenanza FEMP).

Hay, además, otras cinco normas que completan la regulación sobre la mendicidad.

a) En primer lugar, se establece que el Ayuntamiento «adoptará todas las medidas a su alcance para erradicar el fenómeno de la mendicidad en cualquiera de sus formas»; para lo cual «trabajará y prestará la ayuda que sea necesaria para la inclusión social» (art. 37.1 Ordenanza Barcelona; art. 61.1 Ordenanza FEMP).

b) También se establece que «Los agentes de la autoridad, o en su caso, los servicios sociales, informarán a todas las personas que ejerzan la mendicidad en lugares de tránsito público de las dependencias municipales y de los centros de atención institucional o de carácter privado (asociaciones, organizaciones no gubernamentales -ONG-, etc.) a los que pueden acudir para recibir el apoyo que sea necesario para abandonar estas prácticas» (art. 37.2 Ordenanza Barcelona; art. 61.2 Ordenanza FEMP).

c) Con carácter general, se establece la regla de que, en primer lugar, los agentes de la autoridad deben informar a las personas de que están realizando actividades prohibidas; se sancionará cuando «la persona persistiera en su actitud y no abandonara el lugar» (art. 36.1 Ordenanza Barcelona; art. 60.1 y 6 Ordenanza FEMP).

d) Las sanciones pueden «ser sustituidas, de acuerdo con la legislación, por sesiones de atención individualizada con los servicios sociales o por cursos en los que se informará a estas personas de las

43 A juicio de MUÑOZ CONDE, Francisco (2015): 290, son tres los bienes jurídicos protegidos en las tres conductas recogidas en el tipo cualificado: la dignidad de la persona, la libertad y la salud, respectivamente.

${ }^{44}$ CASTIÑEIRAPALOU, M. ${ }^{a}$ Teresa y MONTANER FERNÁNDEZ, Raquel (2015): 222, señalan que es posible interpretar el artículo 232.1 del Código Penal de manera que se incluya el hecho de hacerse acompañar por menores o personas con discapacidad. Aunque también consideran que dicha actuación no debería ser delito, debiendo emplearse otros medios para combatir dicho comportamiento. 
posibilidades de que las instituciones públicas y privadas les ofrezcan asistencia social, así como se les prestará la ayuda que sea necesaria» (art. 36.1 Ordenanza Barcelona; art. 60.1 y 7 Ordenanza FEMP).

e) La última regla aplicable establece que «En todo caso, los agentes de la autoridad procederán a la intervención cautelar de los medios empleados para desarrollar la conducta antijurídica, así como, si es el caso, de los frutos obtenidos» (art. 37.2 Ordenanza Barcelona; art. 61.2 Ordenanza FEMP).

\subsection{Regulación que incide en las actividades cotidianas de las personas sin hogar}

Tanto la Ordenanza de convivencia de Barcelona como la Ordenanza tipo de la FEMP incluyen dos capítulos con idéntica regulación: «Uso impropio del espacio público» (arts. 57 a 60 Ordenanza Barcelona; arts. 83 a 86 Ordenanza FEMP) y «Necesidades fisiológicas» (arts. 42 a 44 Ordenanza Barcelona; arts. 66 a 68 Ordenanza FEMP).

En relación con el primer capítulo, se empieza estableciendo que «Queda prohibido hacer un uso impropio de los espacios públicos y sus elementos, de manera que impida o dificulte la utilización o el disfrute por el resto de los usuarios» (art. 58.1 Ordenanza Barcelona; art. 84.1 Ordenanza FEMP). Dentro de los usos impropios, se señala expresamente que no están permitidos: «Dormir de día o de noche en los espacios» públicos y sus elementos; «Utilizar los bancos y los asientos públicos para usos distintos a los que están destinados»; «Lavarse o bañarse en fuentes, estanques o similares»; y «Lavar la ropa en fuentes, estanques, duchas o similares» (art. 58.2 Ordenanza Barcelona; art. 84.2 Ordenanza FEMP). Todas estas conductas tienen la consideración de infracción leve, sancionadas con multa de hasta 500 euros (art. 59 Ordenanza Barcelona; art. 85 Ordenanza FEMP).

También se establece que, en todos estos casos, «los agentes de la autoridad retirarán e intervendrán cautelarmente el género, los materiales y los medios empleados» (art. 60.1 Ordenanza Barcelona; art. 86.1 Ordenanza FEMP).

Por último, se prevé que no se impondrá sanción, cuando los servicios sociales adopten las medidas procedentes para socorrer o ayudar a estas personas por razones de salud (art. 60.2 Ordenanza de BarceIona; art. 86.2 Ordenanza FEMP) ${ }^{45}$.

El establecimiento de estas prohibiciones se justifica, con carácter general, en «la garantía de un uso racional y ordenado del espacio público y sus elementos»; además, cuando corresponda, en «la salvaguarda de la salubridad, la protección de la seguridad y el patrimonio municipal» (art. 57 Ordenanza Barcelona; art. 83 Ordenanza FEMP).

En el capítulo «Necesidades fisiológicas», se prohíbe «hacer necesidades fisiológicas, como por ejemplo defecar, orinar, escupir» (art. 43.1 Ordenanza Barcelona; art. 67.1 Ordenanza FEMP). Conducta que se considera infracción leve, sancionable con multa de hasta 300 euros, salvo que constituya una infracción más grave (art. 44.1 Ordenanza Barcelona; art. 68.1 Ordenanza FEMP).

La conducta más grave, que está especialmente prohibida, consiste en hacer necesidades fisiológicas en espacios de concurrida afluencia de personas o frecuentados por menores, o cuando se haga en monumentos o edificios catalogados o protegidos (art. 43.2 Ordenanza Barcelona; art. 67.2 Ordenanza FEMP) ${ }^{46}$.

Estas prohibiciones y sanciones relacionadas con las necesidades fisiológicas tienen como fundamento «la protección de la salud pública y la salubridad, el derecho de disfrutar de un espacio público limpio y no degradado, y el respeto a las pautas generalmente aceptadas de convivencia ciudadana y civismo» (art. 42 Ordenanza Barcelona; art. 66 Ordenanza FEMP).

Sin embargo, la regulación parte de la idea de que actuaciones como dormir en la calle o utilizar los bancos y asientos públicos para usos distintos a los que están destinados son perjudiciales en sí mismas. Aun en el caso que alguien durmiera en la calle y no ensuciase el espacio público (por ejemplo, porque recoge los cartones al amanecer y los deposita en un contenedor de papel) se le podría sancionar por dicha acción.

Toda esta regulación relativa a los usos impropios del espacio público y a las necesidades fisiológicas incide directamente en las actividades cotidianas de las personas sin hogar ${ }^{47}$.

\footnotetext{
45 «Los servicios municipales adoptarán en cada caso las medidas que sean procedentes en coordinación con los servicios sociales municipales 0 , si procede, con otras instituciones públicas y, si lo estimaran necesario por razones de salud, acompañarán a estas personas al establecimiento o servicio municipal apropiado, con la finalidad de socorrerlas o ayudarlas en lo posible. En este caso no se impondrá la sanción prevista».

46 El artículo 67.2 de la Ordenanza tipo FEMP es más amplia al incluir también los mercados de alimentos y las proximidades de todos los espacios señalados.

47 En este sentido, POTS, Cory y MARTIN, Lucie (2013): 82, al analizar la normativa local de Bélgica que sigue unos principios generales similares a la regulación local española.
} 


\section{LA PROHIBICIÓN DE REBUSCAR EN LA BASURA EN LAS ORDENANZAS DE CONVIVENCIA Y EN LAS ORDENANZAS DE LIMPIEZA}

Otro elemento importante de la regulación que afecta a las personas sin hogar es la prohibición de rebuscar comida y otros objetos depositados en papeleras y contenedores de basura. Esta cuestión se regula expresamente en la "Ordenanza tipo de seguridad y convivencia ciudadana» de la FEMP, dentro del Capítulo denominado «Limpieza de la vía pública a consecuencia de obras y actividades diversas». Según su artículo 28.13 «Se prohíbe rebuscar, hurgar y extraer elementos depositados en las papeleras y recipientes instalados en la vía pública». Incumplir esta prohibición se considera infracción leve, según la tipificación residual del artículo 161; sancionable con multa de hasta 750 euros en virtud del artículo 162.

No se señala expresamente cuál es el fundamento de esta regulación, aunque parece claro que responde a la finalidad de mantener limpias las vías públicas. Es destacable que la Ordenanza de convivencia de Barcelona no incluye cuestiones relacionadas con la limpieza de la vía pública. Aunque hay municipios que sí han incluido en su ordenanza de convivencia la prohibición de rebuscar en la basura.

Así, se puede mencionar la «Ordenanza municipal para la protección de la convivencia ciudadana y prevención de actuaciones antisociales» de San Sebastián de los Reyes (Madrid), de 21 de febrero de 2008. La Ordenanza prohíbe «Remover y extraer los residuos de papeleras y contenedores selectivos» [artículo 26.f)]. Se considera infracción leve, según la tipificación residual establecida en el artículo 80; sancionable entre 30 y 750 euros. Y la «Ordenanza municipal sobre comportamiento cívico y reguladora del uso, ocupación y limpieza de la vía pública» de Irún. Según su artículo 21.2: "Queda prohibido rebuscar y extraer residuos depositados en las bolsas de basura y en los contenedores instalados en la vía pública, incluidos los destinados a recogida de desechos de obras». El incumplimiento de esta prohibición tiene la consideración de infracción leve (art. 61.3); sancionable con multa de 60 a 750 euros (art. 62.1).

Otro de los instrumentos normativos para prohibir las actividades de rebuscar en la basura han sido las ordenanzas de limpieza. Se puede mencionar la «Ordenanza de Limpieza de los Espacios Públicos y Gestión de Residuos» del Ayuntamiento de Madrid, de 27 de febrero de $2009^{48}$. Esta ordenanza prohíbe «Manipular, rebuscar o extraer residuos depositados en recipientes instalados en la vía pública» [artículo 14.j)].

Se considera infracción leve «Manipular, rebuscar o extraer residuos depositados en recipientes instalados en la vía pública, de conformidad con el artículo 14.j)» [artículo 86.1.d)]. Como infracción leve se sanciona con una multa de hasta 750 euros [artículo 89.1.c)]

El fundamento de la prohibición de rebuscar en la basura parece estar en consideraciones de ornato e higiene. Así, según el artículo 14 de la Ordenanza de limpieza de Madrid, las prohibiciones recogidas en dicho precepto, entre las que se encuentra la prohibición de rebuscar en la basura, se establecen «Por su especial repercusión en el ornato e higiene de la ciudad».

La Ordenanza de limpieza establece una prohibición general de ensuciar los espacios públicos. Según su artículo 13.1, «Se prohíbe abandonar en la vía pública o, en general, en cualquier espacio público, cualquier tipo de residuo, así como realizar cualquier otra conducta que pueda ensuciar la vía o espacios públicos o ir en detrimento de su higiene y aseo». Prohibición que se completa con la infracción leve genérica «Arrojar o verter residuos que ensucien los espacios públicos» [artículo 86.1.c)].

Parece, por tanto, que no se sanciona rebuscar en la basura porque se ensucian las calles. Sería suficiente a estos efectos con la prohibición contenida en el artículo 13.1, sancionada en el artículo 86.1.c). Sino que se considera que rebuscar en la basura es una acción lesiva por sí misma, un comportamiento inadecuado que por sí mismo es contrario al ornato e higiene de la ciudad. De manera que no es condición necesaria para poder imponer la sanción que se ensucie un espacio público, es suficiente con que se rebusque en la basura o se extraigan residuos.

Una regulación similar se recoge en la «Ordenanza municipal de limpieza pública y gestión de residuos municipales» del Ayuntamiento de Sevilla, de 25 de julio de 201449. La Ordenanza establece que «Queda prohibido extraer o rebuscar residuos una vez depositados en los contenedores» (art. 11.19). Esta prohibición se considera incluida expresamente dentro de la prohibición genérica establecida en el primer párrafo del artículo 11: «Se prohíben cuantas conductas o acciones produzcan ensuciamiento de la vía pública o sean contrarias a lo establecido en esta Ordenanza». Se tipifica como infracción leve: «La manipulación, extracción o rebusca

\footnotetext{
48 Boletín Oficial del Ayuntamiento de Madrid de 24 de marzo de 2009.

49 Boletín Oficial de la provincia de Sevilla, de 9 de octubre de 2014, págs. 34 a 57.
} 
REALA. Nueva Época - N. ${ }^{6}$, noviembre 2016 - ISSN: 1989-8975 - DOI: 10.24965/reala.v0i6.10384 - [Págs. 7-26]

Las ordenanzas locales como instrumento de exclusión social: la regulación que afecta a las personas sin hogar es derecho ...

Eduardo Melero Alonso

de los residuos una vez puestos a disposición de los servicios municipales en la forma establecida en esta Ordenanza» (artículo 120); sancionable con una multa desde 90 euros hasta 750 euros (artículo 121).

\section{ANÁLISIS CRÍTICO DE LAS ORDENANZAS LOCALES EN RELACIÓN CON LAS PERSONAS SIN HOGAR}

\subsection{Competencia de los municipios para dictar estas ordenanzas}

En la exposición de motivos de la Ordenanza tipo de la FEMP, ésta se vincula con la competencia atribuida en los artículos 139 a 141 de la LRBRL, introducidos por la Ley 57/2003, de 16 de diciembre, de medidas de modernización del gobierno local ${ }^{50}$ Esta fundamentación ha sido criticada, partiendo de que la potestad sancionadora es un potestad instrumental ${ }^{51}$.

La competencia para dictar las ordenanzas de convivencia podría justificarse en la actividad de policía, entendida como limitación a «la libertad de los ciudadanos con el fin de que no se perturbe o ponga en peligro el orden público», interpretando conjuntamente los artículos 84 LRBRL y 1.1 del Reglamento de Servicios de las Corporaciones Locales ${ }^{52}$. También se ha considerado que los municipios pueden aprobar ordenanzas en aquellas cuestiones que se consideren como una necesidad de la comunidad vecinal, con base en el artículo $25.1 \mathrm{LRBRL}^{53}$.

La modificación de la LRBRL llevada a cabo por la Ley 27/2013, de 27 de diciembre, de racionalización y sostenibilidad de la Administración Local no afecta a esta cuestión. Aunque ha desaparecido del artículo 25 LRBRL la competencia municipal sobre seguridad en lugares públicos, se mantiene la vigencia del artículo 1.1 del Reglamento de Servicios de las Corporaciones Locales que permite que los Ayuntamientos intervengan en el ejercicio de la función de policía. Por otra parte, el nuevo artículo 7.4 LRBRL permite a las entidades locales que asuman voluntariamente competencias, siempre que no se ponga en riesgo la sostenibilidad financiera del municipio y se trate de servicios que no están ejecutando simultáneamente otras administraciones ${ }^{54}$.

En cualquier caso, esta cuestión no afecta a las Ordenanzas que establecen la prohibición de rebuscar en la basura. Regulación que tiene su base en las competencia municipal sobre el medio ambiente urbano y la gestión de los residuos sólidos urbanos [art. 25.2.b) LRBRL].

\subsection{Sanciones no pecuniarias previstas en las ordenanzas}

La mayoría de sanciones relacionadas con la conducta de personas sin hogar que han establecido las ordenanzas consisten en multas económicas. En cuestiones de mendicidad, además, se establece la posibilidad de sustituir las sanciones por sesiones de atención individualizada con los servicios sociales o por cursos. También se señala que los agentes de la autoridad intervendrán cautelarmente los medios empleados para desarrollar la conducta antijurídica y los frutos obtenidos; regulación que también existe en las prohibiciones relacionadas con el uso impropio de los espacios públicos.

Este tipo de medidas no están previstas expresamente en la LRBRL, cuyo artículo 141 sólo prevé la posibilidad de imponer sanciones económicas ${ }^{55}$. Aunque se ha flexibilizado la reserva de ley en materia de sanciones locales, según la jurisprudencia constitucional la ley debe establecer los tipos de sanciones que pueden establecer las ordenanzas (STC 132/2001, de 8 de junio, FJ 6). Este tipo de sanciones no pecuniarias son, por tanto inconstitucionales, a no ser que estén previstas en una ley sectorial, sea estatal o autonómica ${ }^{56}$.

${ }^{50}$ La Ordenanza de Barcelona también hace referencia a las competencias municipales, partiendo de la idea de que es una norma transversal, que afecta a muchas de tales competencias.

51 A juicio de CASINO RUBIO, Miguel (2011): 759-762, el artículo 139 LRBRL no atribuye nuevas competencias a los municipios. Su punto de partida es que la potestad sancionadora es una potestad instrumental, por tanto, para poder establecer infracciones hay que tener atribuida la competencia material.

52 Véase REBOLLO PUIG, Manuel e IZQUIERDO CARRASCO, Manuel (2007): 2189-2196; la cita corresponde a la página 2191. En contra, CASINO RUBIO, Miguel (2011): 767, considera que la competencia de orden público no puede justificar la adopción de medidas de policía normativas; tesis que desarrolla algo más en (2012): 17-18.

53 ORTEGA BERNARDO, Julia (2014): 52.

54 ORTEGA BERNARDO, Julia (2014): 339-341 y ORDUÑA PRADA, Enrique (2016): 309-310.

${ }_{55}$ Así, PEMÁN GAVÍN, Juan M. ${ }^{a}$ (2010): 41-42, quien considera problemática la previsión de sanciones que no consistan en multas, incluyendo el comiso de los bienes o instrumentos empleados para la comisión de la infracción.

${ }^{56}$ Véase VELASCO CABALLERO, Francisco (2009): 274; en sentido similar ORDUÑA PRADA, Enrique (2016): 225-226 y $339-341$ 


\subsection{Derechos de las personas sin hogar implicados: análisis del libre desarrollo de la personalidad, la libertad de expresión y el derecho a la libertad personal}

En mi opinión, el problema jurídico más importante relacionado con estas ordenanzas es su incidencia en el ejercicio de los derechos fundamentales ${ }^{57}$. En este caso, en el ejercicio de los derechos fundamentales de las personas sin hogar.

El punto de partida es que las ordenanzas de convivencia no tienen en cuenta este aspecto: que las personas sin hogar también son titulares de derechos fundamentales. Esto se pone de manifiesto claramente en los artículos en los que se menciona el fundamento en que se basa la regulación.

Son tres los derechos que se van analizar: el libre desarrollo de la personalidad (art. 10.1 CE), la libertad de expresión (art. 20 CE) y el derecho a la libertad personal (art. 17.1).

1. En cuanto al libre desarrollo de la personalidad, doctrinalmente se entiende que es un principio interpretativo, que no garantiza ámbitos concretos de libertad ${ }^{58}$. En otras palabras, no impide a los poderes públicos, a priori, prohibir determinadas conductas ${ }^{59}$. Uno de los efectos de este principio sería «una interpretación restrictiva de los límites legales, aun con fundamento constitucional, de la libertad negativa garantizada, también, por cada concreto derecho fundamental» ${ }^{60}$.

Por tanto, el libre desarrollo de la personalidad no supone un límite a la posibilidad de que las ordenanzas locales prohíban la mendicidad, dormir en la calle o rebuscar en la basura.

2. La libertad de expresión se ve afectada por las ordenanzas que prohíben la mendicidad ${ }^{61}$. A mi juicio, esta postura se puede fundamentar a partir de un reconocimiento amplio del derecho a la libertad de expresión. El aspecto clave es si la libertad de expresión se limita a mensajes de contenido político o va más allá.

Desde una concepción restrictiva, se entiende que el núcleo de la protección de la libertad de expresión e información se refiere a cuestiones políticas; resultando dudoso si los mensajes de contenido no político están cubiertos por este derecho, salvo que se refieran a cuestiones de tipo artístico o científico en cuyo caso estarían amparados por la libertad de creación científica o artística también protegidas en el artículo $20 \mathrm{CE}^{62}$.

Desde una concepción más amplia, se entiende que el objeto de la libertad de expresión es indeterminado; protege «cualquier tipo de mensaje, sea o no político», «cualquier tipo de pensamiento, idea o hecho y no sólo los de naturaleza política» ${ }^{63}$.

Esta concepción amplia me parece más coherente con la consideración de este derecho como un derecho de libertad frente al poder ${ }^{64}$. El Tribunal Constitucional no ha limitado el derecho a la libertad de expresión a mensajes de tipo político ${ }^{65}$. Así, ha entendido que el derecho a recibir información también se refiere a acontecimientos deportivos de interés general ${ }^{66}$. La relevancia pública del mensaje ${ }^{67}$, su contribución a la formación de una opinión pública libre ${ }^{68}$, son circunstancias a tener en cuenta al establecer el grado de

57 Esta cuestión ha sido analizada con exhaustividad por ORTEGA BERNARDO, Julia (2014): 47-192. Como pone de manifiesto esta autora, hay ordenanzas locales que inciden: en el principio de libre desarrollo de la personalidad (art. $10.1 \mathrm{CE}$ ); en el derecho a la vida, a la integridad física o moral (art. $15 \mathrm{CE}$ ); en el derecho a la vida privada, a la intimidad personal y familiar (art. 18.1 CE); en el derecho a la inviolabilidad del domicilio (art. 18.2 CE); en el derecho a la libertad religiosa (art. $16 \mathrm{CE}$ ); en la libertad de expresión e información (art. $20 \mathrm{CE}$ ); en el derecho a la legalidad sancionadora (art. $25 \mathrm{CE}$ ); en el derecho de propiedad privada (art. 33 CE); o en el derecho a la libertad de empresa (art. $38 \mathrm{CE})$.

58 JIMÉNEZ CAMPO, Javier (2008): 187-189; seguido por ORTEGA BERNARDO, Julia (2014): 48-49. JIMÉNEZ CAMPO, Javier (2008): 188-189, sí reconoce que en algún caso concreto el principio de libre desarrollo de la personalidad puede limitar al legislador, en supuestos de paternalismo moral (188-189).

59 ORTEGA BERNARDO, Julia (2014): 51.

60 JIMÉNEZ CAMPO, Javier: 2008, 188

61 Así lo señala ORTEGA BERNARDO, Julia (2014): 37 (nota 7), sin justificar su postura.

62 DIEZ PICAZO, Luis María (2008): 336.

63 SOLOZÁBAL ECHAVARRÍA, Juan José (2011): 200. VILLAVERDE MENÉNDEZ, Ignacio (2008): 477, no limita el ejercicio del derecho a libertad de expresión a las opiniones políticas.

64 STC 6/1981, de 16 de marzo, FJ 4; STC 112/2006, de 5 de abril, FJ 11.

65 La STC 11/2000, de 17 de enero, FJ 8, utiliza el término genérico «mensaje» al referirse a las circunstancias que se deben tener en cuenta al fijar su grado de protección: la relevancia pública del asunto, el carácter de personaje público de la persona sobre la que se emite la opinión, el contexto en que se produce y, sobre todo, si contribuye a la formación de una opinión pública libre.

66 STC 112/2006, de 5 de abril, FJ 11.

67 STC 11/2000, de 17 de enero, FJ 8. En este sentido, VILLAVERDE MENÉNDEZ, Ignacio (2008), 478, señala que «la "relevancia pública" de la opinión o la información divulgadas ha sido usada por el Tribunal Constitucional como criterio decisivo de la "proporcionalidad" de los límites que debe soportar la libertad de expresión, antes que para definir su objeto».

68 STC 336/1993, de 15 de noviembre, FJ 4; STC 11/2000, de 17 de enero, FJ 8. 
REALA. Nueva Época - N. ${ }^{6}$, noviembre 2016 - ISSN: 1989-8975 - DOI: 10.24965/reala.v0i6.10384 - [Págs. 7-26]

Las ordenanzas locales como instrumento de exclusión social: la regulación que afecta a las personas sin hogar es derecho ...

Eduardo Melero Alonso

protección de este derecho. Pero eso no implica que los mensajes en que no concurran quedan fuera del ámbito de protección de la libertad de expresión.

Desde mi punto de vista, la mendicidad es una conducta que consiste, en gran medida, en la emisión de un mensaje que puede ser verbal, escrito o incluso simbólico ${ }^{69}$. Incluso cuando la mendicidad se lleva a cabo a través del ofrecimiento de objetos, como pañuelos de papel, la prestación de un servicio, o se plasma en la realización de algún tipo de espectáculo público. En estos casos prima el mensaje de pedir algo para vivir frente al ofrecimiento de objetos, la prestación de un servicio o realización de un espectáculo. Estas actividades son los medios a través de los cuales se articula el mensaje.

3. A juicio de la Sentencia del Tribunal Superior de Justicia de Castilla y León, Valladolid, Sala de lo Contencioso-administrativo, de 8 de octubre de 2013, FJ 10 (JUR|2013|330557), en la regulación de la mendicidad, el derecho implicado es el «principio de libertad de la persona (art. 9.2 y $18 \mathrm{CE}$ )» [sic.].

«A juicio de la Sala, la mendicidad puede ofrecer diferentes aspectos cuya delimitación condicionan el análisis que se haga. La mera petición de dinero, de tabaco, de transporte... etc., hecha por un no indigente, no es tal acción de mendigar. El problema se plantea cuando quien solicita limosna (dinero), lo hace con importunidad. Por tal hemos de entender la incomodidad o molestia causada por esa solicitud de entrega de dinero. Del restante tenor literal del precepto sí se coligen actos de mendicidad que rebasan, sin duda el límite de lo tolerable (uso de menores, en las calzadas, de modo coactivo o limite o dificulte el tránsito de peatones o vehículos), mereciendo el calificativo de importunas, como también lo son los actos de mendicidad realizados por personas integradas en estructuras organizadas. Pero considerar legítimo prohibir una simple petición, hecha en verdadero estado de necesidad, de forma educada, no reiterada, excede a un principio fundamental como es la libertad de las personas.

Es pues el problema, la redacción del precepto, pues habla de cualquier forma de mendicidad.

Es legítimo, como se dijo, sancionar la situación de mayor o menor coacción, conflicto moral, violencia psíquica o mera incomodidad que el ejercicio de la mendicidad acarrea al ciudadano.»

En esta sentencia el TSJ anuló el artículo 15.1 de la ordenanza «por vulneración del principio de libertad de la persona (art. 9.2 y $18 \mathrm{CE}$ ) [sic] ${ }^{70}$. El artículo 15 de la Ordenanza Municipal de Protección de la Convivencia Ciudadana y Prevención de Actuaciones Antisociales, de Valladolid, de 6 de marzo de $2012^{71}$, establecía que: «Quedan prohibidas las conductas que adopten cualquier forma de mendicidad en las vías y espacios públicos».

En mi opinión, el derecho a la libertad personal (art. 17.1 CE) no se encuentra implicado prioritariamente en la regulación de la mendicidad sino en las ordenanzas que, entre otras conductas, prohíben tanto dormir en los espacios públicos como utilizar los bancos y asientos públicos para usos distintos a los que están destinados ${ }^{72}$.

El derecho a la libertad personal del artículo 17.1 CE no establece una cláusula general de libertad ${ }^{73}$. Su ámbito es más limitado: protege la libertad física ${ }^{74}$, «la libertad frente a la detención, condena o internamientos arbitrarios» ${ }^{75}$, la libertad para orientar la propia acción en el marco de las normas generales ${ }^{76}$, «la facultad del individuo de moverse, de situarse en el espacio» ${ }^{77}$; «consiste en la plena autodeterminación del propio movimiento corporal» ${ }^{78}$.

69 La posibilidad de que la libertad de expresión se ejerza a través de conductas simbólicas ha sido reconocida por DIEZ PICAZO, Luis María (2008): 336. Véase también la STC 177/2015, de 22 de julio, FJ 3.b).

70 Considero que hay una errata y que el TSJ se quiere referir al artículo $17 \mathrm{CE}$, libertad personal.

71 Boletín Oficial de la Provincia de Valladolid de 31 de marzo.

72 BALAGUER PÉREZ, Amalia (2014): 704-707, considera que resultan afectados el derecho a la libertad personal, el derecho a la libre circulación e incluso el derecho a la salud.

73 GARCÍA TORRES, Jesús y REQUEJO PAGÉS, Juan Luis (2011): 158; REY, Fernando (2013): 533. Según la STC 120/1990, de 27 de junio, FJ 11, el artículo 17.1 CE no garantiza «una libertad general de actuación o una libertad general de autodeterminación individual»; en idéntico sentido STC 137/1990, de 19 de julio, FJ 9.

74 STC 23/1985, de 15 de febrero, FJ 2.

75 STC 120/1990, de 27 de junio, FJ 11; STC 137/1990, de 19 de julio, FJ 9. En un sentido similar, según la STC 126/1987, de 16 de julio, FJ 4, «el art. 17 es un derecho a la seguridad personal y por consiguiente a la ausencia de perturbaciones procedentes de medidas de detención o de otras similares, que puedan restringir la libertad personal o ponerla en peligro».

76 STC 341/1993, de 18 de noviembre, FJ 4

77 LASCURAÍN SÁNCHEZ, Juan Antonio (2008): 366.

78 GARCÍA TORRES, Jesús y REQUEJO PAGÉS, Juan Luis (2011): 158; en un sentido similar, REY, Fernando (2013): 533. 
Partiendo de esta doctrina y jurisprudencia, el derecho a la libertad personal del artículo 17.1 CE no estaría implicado en la regulación que afecta a las actividades cotidianas de las personas sin hogar, ya que no protege un ámbito general de libertad.

Desde mi punto de vista, esta solución no tendría en cuenta la especial situación en la que se encuentran las personas sin hogar. Partiendo de que el derecho de propiedad privada permite a su titular prohibir el uso de sus bienes a otras personas, los espacios públicos son el único sitio donde las personas sin hogar van a poder realizar determinadas actividades. Como ha señalado Jeremy WALDRON, «sin una casa, la libertad de una persona es su libertad para actuar en público, en lugares regidos por las normas de la propiedad común» ${ }^{79}$; para concluir que: «Si dormir está prohibido en los lugares públicos, entonces dormir está totalmente prohibido para los sin hogar. Si orinar está prohibido en los lugares públicos (y no hay baños públicos) entonces los sin hogar simplemente no son libres para orinar» ${ }^{80}$. De esta forma, actividades que no están prohibidas con carácter general, sí lo estarían para las personas sin hogar.

El derecho a la libertad personal no solo está implicado en los supuestos de detención preventiva, detención policial, habeas corpus y prisión provisional, que son las cuestiones reguladas en los demás apartados del artículo 17 CE. Se aplica a cualquier restricción del derecho ${ }^{81}$. En mi opinión, la prohibición de dormir en espacios públicos y/o utilizar los bancos y asientos públicos para usos distintos a los que están destinados, la prohibición de lavarse en fuentes y la prohibición de hacer las necesidades fisiológicas en espacios públicos suponen una restricción al derecho de libertad personal del artículo 17.1 CE ${ }^{82}$.

\subsection{Parámetros de control de las ordenanzas que inciden en los derechos de las personas sin hogar}

\subsubsection{Reserva de ley en materia de derechos fundamentales}

La incidencia de las ordenanzas locales en los derechos fundamentales implica el problema de la delimitación de la intensidad de la reserva de ley en este ámbito (arts. 53.1 y $81 \mathrm{CE}$ ). En esta cuestión se han planteado dudas sobre si es suficiente una ordenanza para prohibir conductas que afectan a los derechos fundamentales, o es necesaria una ley orgánica ${ }^{83}$. En este sentido, según la Sentencia del Tribunal Supremo de 14 de febrero de 2013 (número de recurso 4118/2011), FJ 7, «todo el ejercicio del derecho fundamental está reservado a la Ley, y no puede por ello ser objeto directo de regulación por una Ordenanza municipal» ${ }^{84}$.

También se ha planteado la flexibilización de la reserva de ley en materia de derechos fundamentales en el ámbito local, utilizando los mismos argumentos por los que se justificó la flexibilización de la reserva de ley en materia sancionadora en el ámbito local ${ }^{85}$. Desde esta postura se plantea que la ley debe determinar la prevalencia de unos derechos o intereses frente a otros o, al menos, debe identificar los derechos o principios en conflicto ${ }^{86}$.

Desde ambos puntos de vista, las ordenanzas serían contrarias a derecho. Según la jurisprudencia del Tribunal Supremo, estas ordenanzas regulan directamente los derechos fundamentales de las personas sin hogar. Tampoco hay una ley previa, en la que se dé prevalencia o se identifiquen los principios en conflicto, que amparara una interpretación flexible de la reserva de ley.

79 WALDRON, Jeremy (1991-1992): 311.

80 WALDRON, Jeremy (1991-1992): 315. Argumento utilizado por BALAGUER PÉREZ, Amalia (2014): 711-712, quien señala que «si se prohíbe dormir en el espacio público y una persona no dispone de espacio privado en el que dormir, la prohibición de dormir se convierte en general para ella».

${ }^{81}$ En este sentido, GARCÍA TORRES, Jesús y REQUEJO PAGÉS, Juan Luis (2011): 158, consideran que el derecho a la libertad y seguridad personales «no sólo da protección contra las privaciones arbitrarias de libertad, sino también contra cualesquiera restricciones menos intensas que la privación».

${ }^{82}$ El Convenio Europeo de Derechos Humanos permite, en su artículo 5.1.e), que por ley se prive de la libertad a los vagabundos. Una medida que sí ha tomado Hungría. Sobre la jurisprudencia del TEDH en relación con dicho artículo véase BALAGUER PÉREZ, Amalia (2014): 701-705 (en la página 696 explica el caso húngaro).

83 CASINO RUBIO, Miguel (2011): 765

${ }^{84}$ Esta sentencia anuló la modificación de la Ordenanza de Civismo y Convivencia de Lleida que prohibía el uso del velo integral en dependencias municipales, «por vulneración del derecho de libertad religiosa, art. 16.1 CE, al no existir Ley previa con base a la que pudiera limitarse el ejercicio de tal libertad en lo relativo al uso del atuendo cuestionado» (FJ 14).

85 ORTEGA BERNARDO, Julia (2014): 199-200.

${ }^{86}$ ORTEGA BERNARDO, Julia (2014): 205-206. Para esta autora, las ordenanzas sólo pueden incidir de manera puntual en los derechos fundamentales, pero no llevar a cabo una regulación general del ejercicio de derecho; aunque la incidencia afecte a aspectos esenciales y no accesorios del derecho (véase págs. 212-214). 


\subsubsection{Principio de proporcionalidad y ordenanzas locales que afectan a las personas sin hogar}

El principio de proporcionalidad implica «la proscripción de todo sacrificio de la libertad inútil, innecesario o desproporcionado»; un principio que deriva del Estado de Derecho y el valor justicia reconocidos en el artículo $1.1 \mathrm{CE}^{87}$. Según la doctrina mayoritaria, este principio entra en juego frente a las intervenciones de los poderes públicos en la libertad de los ciudadanos; entendida esta libertad en sentido amplio, como ámbito de autodeterminación de las personas ${ }^{88}$. El juicio de proporcionalidad exige que se identifique la finalidad de la medida pública adoptada, finalidad que se convierte en el «parámetro a través del cual enjuiciar la medida» 89 .

Por tanto, el principio de proporcionalidad puede utilizarse como parámetro de control de las ordenanzas locales que inciden en las actividades diarias de las personas sin hogar. Incluso aunque no haya un derecho fundamental afectado, como sucede en el caso de las ordenanzas que prohíben rebuscar en la basura.

Como técnica jurídica concreta, este principio se pone en práctica a través de tres criterios de aplicación sucesiva: 1) idoneidad: la medida limitadora debe ser un medio apto para alcanzar el fin público que se pretende alcanzar; 2) necesidad: no ha de existir otra medida menos gravosa e igualmente eficaz para alcanzar el fin previsto; y 3) proporcionalidad en sentido estricto (o ponderación): las ventajas que se alcanzan al proteger un determinado fin público deben compensar los perjuicios ocasionados al derecho limitado ${ }^{90}$. Teniendo en cuenta que la vulneración del principio de proporcionalidad requiere que se trate de una desproporción extrema, evidente y manifiesta ${ }^{91}$.

En este apartado analizaré los dos primeros criterios de este principio, dejando para el siguiente el estudio de las exigencias que impone la técnica de la ponderación.

En cuanto al requisito de la idoneidad, considero que, con carácter general, concurre en la regulación de las ordenanzas que afecta a las personas sin hogar. Las prohibiciones y sanciones establecidas son un medio apto para alcanzar los objetivos que se plantean en dichas normas: protección frente a determinadas formas de mendicidad, uso del espacio público, salubridad...

En mi opinión, la única regulación problemática en cuanto a la idoneidad es la prohibición de rebuscar en la basura. Una prohibición que se establece con el fin de garantizar el ornato e higiene de la ciudad. Más bien parece que la finalidad pretendida es impedir la imagen de personas buscando alimentos y otros objetos en los contenedores. Aunque la ausencia de idoneidad no se deduce de manera evidente y manifiesta.

En cuanto al requisito de la necesidad, el elemento común es si hay alguna medida menos gravosa que la sanción e igualmente eficaz para alcanzar el fin que se propone la norma. Considero que debe considerarse una medida menos gravosa el establecimiento de una sanción con un ámbito de aplicación considerablemente menor que la sanción establecida previamente.

En relación con las prohibiciones relativas a la mendicidad, entiendo que sí existe la necesidad en los supuestos en que sea ejercida utilizando auténtica coacción, o sea realizada por menores o con menores. En los demás supuestos de mendicidad, siempre que exista una política municipal social al respecto y las sanciones se aplicaran como medida de último recurso, se cumplirían las exigencias de la necesidad.

En cuanto a las sanciones relativas al uso impropio del espacio público, en mi opinión no hay necesidad en aquellas prohibiciones que no implican un daño real a los bienes de dominio público: como la prohibición de dormir, la prohibición de usar bancos de forma inapropiada...Una medida menos gravosa sería imponer sanciones únicamente a las personas que ensucien la calle o causen daños en bienes de dominio público. De esta manera se conseguiría el mismo resultado que pretende alcanzar la ordenanza.

87 BARNÉS, Javier (1998): 19; también lo fundamenta en el principio del Estado de Derecho RODRíGUEZ DE SANTIAGO, José María (2000): 106

${ }_{88}$ Véase RODRÍGUEZ DE SANTIAGO, José María (2000): 106 y 110. En esta misma línea se sitúa BARNÉS, Javier (1998): 21, al afirmar que el principio de proporcionalidad «en cuanto escudo que acompaña a cualquier situación de ventaja reconocida por el ordenamiento -y no sólo a los derechos fundamentales-, podrá ser alegada (con base, en esencia, en el art. 1.1 CE) ante cualquier jurisdicción, siempre que la restricción o gravamen sea obra del poder público».

Hay propuestas doctrinales más amplias, que consideran que el principio de proporcionalidad ha de aplicarse a cualquier situación en la que se ponderen principios en conflicto; véase ARROYO JIMÉNEZ, Luis (2009): 39. Téngase en cuenta que este autor no identifica ponderación y el tercer escalón del principio de proporcionalidad.

${ }^{89}$ BARNÉS, Javier (1998): 25, para quien «La finalidad es la que determina, en cada caso, el peso y la medida máxima que se le puede consentir a la injerencia».

90 RODRÍGUEZ DE SANTIAGO, José María (2000): 105. En el mismo sentido, BARNÉS, Javier (1998): 18.

91 Véase BARNÉS, Javier (1998): 16, 44 y 45. 
En cuanto a las sanciones por realizar las necesidades fisiológicas en espacios públicos, siempre que exista una red de baños públicos suficiente, concurre la necesidad. $\mathrm{O}$, al menos, no es manifiesta su falta de concurrencia.

Por último, considero que, manifiestamente, no existe necesidad en la prohibición de rebuscar en la basura. Se sanciona el mero hecho de rebuscar con independencia de que se produzca un resultado dañoso. Debería sancionarse solamente a aquellas personas que ensucian la calle o que estropean los contenedores de residuos urbanos; así se alcanzaría el mismo resultado que pretende la normativa con una medida menos gravosa.

\subsubsection{Ponderación entre los derechos de las personas sin hogar y los derechos y bienes jurídicos protegidos por las ordenanzas}

Las ordenanzas locales que afectan a las personas sin hogar implican un conflicto entre distintos derechos, bienes e intereses en conflicto. Algo que es habitual en este tipo de normas. En este sentido, se ha calificado a las ordenanzas locales como «decisión ponderativa» ${ }^{92}$.

La ponderación es el tercer elemento del principio de proporcionalidad. La ponderación es un método para resolver los conflictos entre derechos, principios y bienes, que consta de tres fases ${ }^{93}$. En primer lugar, se identifican los derechos, principios, bienes o intereses en conflicto. En la segunda fase, se atribuye a cada derecho o principio un peso o importancia, atendiendo a las circunstancias del caso. Por último, se otorga prevalencia a uno de los derechos, principios,... en conflicto, con base en el criterio de que "cuanto mayor sea el grado de perjuicio del principio que retrocede mayor debe ser la importancia del que prevalece en el caso determinado» ${ }^{94}$.

\subsubsection{Ponderación entre mendicidad y libertad de expresión.}

Antes de analizar esta cuestión, considero que el ejercicio de la mendicidad a través de «actitudes coactivas o de acoso» debe quedar fuera de la ponderación, ya que estas actuaciones no se incluyen dentro del ámbito de protección del derecho a la libertad de expresión ${ }^{95}$. Siempre que se trate de auténticas coacciones según lo que establece el Código Penal y no de presunciones, como la establecida en la ordenanza de Sevilla sobre el ofrecimiento de un lugar para aparcar. Si el insulto no queda protegido por la libertad de expresión ${ }^{96}$, con mayor razón han de quedar fuera las actuaciones coactivas.

Los derechos o bienes en conflicto son, por un lado, la libertad de expresión, por otro, según el texto de la ordenanza «el derecho que tienen los ciudadanos y ciudadanas a transitar por el Municipio [...] sin ser molestados o perturbados en su voluntad, la libre circulación de las personas, la protección de menores, así como el correcto uso de las vías y los espacios públicos».

Una primera advertencia aquí es que no existe un derecho a no sufrir molestias cuando se transita por la calle. La libertad física, como se señaló, es protegida por el derecho a la libertad personal del artículo 17.1 CE. Mientras que la libertad de movimientos se encuentra amparada por el derecho a la libre circulación del artículo $19 \mathrm{CE}^{97}$. Ambos derechos no incluyen en su contenido que no se puedan sufrir molestias causadas por la actuación de otras personas. Molestias que son consecuencia última de la vida en sociedad ${ }^{98}$; y que,

92 ORTEGA BERNARDO, Julia (2014): 207, puntualizando que dicha ponderación se realiza en el marco de las preferencias prima facie adoptadas por el legislador.

${ }^{93}$ En relación con las tres fases de la ponderación, véase RODRÍGUEZ DE SANTIAGO, José María (2000): 121-141.

94 RODRÍGUEZ DE SANTIAGO, José María (2000): 135-136.

95 Se trataría de un falso problema de ponderación. Sobre los falsos problemas de ponderación, véase RODRÍGUEZ DE SANTIAGO, José María (2000): 121-122.

96 STC 105/1990, de 6 de junio, FJ 8

97 Para BASTIDA FREIJEDO, Francisco J. (2011): 166, el contenido sustancial del derecho a la libre circulación consiste en «la libertad de ir y venir, la libertad de movimientos»; entendido además como un derecho de libertad que implica la no injerencia de los poderes públicos (pág. 167). En un sentido similar, LOSADA GONZÁLEZ Herminio (2008): 464.

98 Viene a cuento aquí la opinión del Fiscal recogida en la STS de 14 de febrero de 2013 (recurso 4118/2011), FJ 6, sentencia que valora la prohibición del velo integral en instalaciones municipales:

«Cree el Fiscal que la perturbación de la convivencia a que la norma se refiere ha de tener un mínimo de relevancia en cualquiera de sus modalidades, siendo luego la intensidad de su afectación a la tranquilidad (o al ejercicio de derechos legítimos de otros, que evidentemente no es el caso) lo que permitirá calificar la conducta como muy grave, grave o leve. Negar esta afirmación supondría aceptar la tipicidad de perturbaciones irrelevantes de la convivencia, lo que no parece de recibo. 
REALA. Nueva Época - N. 6, noviembre 2016 - ISSN: 1989-8975 - DOI: 10.24965/reala.v0i6.10384 - [Págs. 7-26]

Las ordenanzas locales como instrumento de exclusión social: la regulación que afecta a las personas sin hogar es derecho ..

Eduardo Melero Alonso

por tanto, deben ser asumidas por las personas siempre que no alcancen una especial gravedad, como puede ser la realización de coacciones. En otras palabras, las meras molestias no son suficientes para limitar los derechos fundamentales ${ }^{99}$.

En relación con la mendicidad ejercida directamente por menores o con menores, el artículo 20.4 CE establece que el derecho a la libertad de expresión tiene como límite, entre otros, «la protección de la juventud y de la infancia». Además hay que tener en cuenta el artículo 39.4 CE. Este artículo establece que los niños gozarán de la protección prevista en los acuerdos internacionales que velan por sus derechos. Lo que implica, especialmente, que ha de prevalecer el «interés superior del niño» en virtud del artículo 3.1 de la Convención sobre los Derechos del Niño ${ }^{100}$. De manera que, habrá que otorgar prevalencia a la protección de los menores en estos casos.

Lo mismo sucede con las personas con discapacidad, a las que el artículo 49 CE garantiza su autonomía y autodeterminación personal y su integridad como sujeto autónomo de derechos ${ }^{101}$.

A la hora de atribuir importancia a los derechos o bienes en conflicto, considero que ha de partirse del hecho de que «la mendicidad es el único medio de vida que tienen muchas de estas personas» ${ }^{102}$. Aunque se trate de un hecho, no ponderable por tanto, se puede utilizar para otorgar prevalencia a un derecho frente a otro ${ }^{103}$.

Cuando se impida efectivamente el libre tránsito de las personas, algo que sucederá en casos muy excepcionales, habrá que otorgar prioridad al derecho a la libre circulación de quienes no ejercen la mendicidad. Por tanto, habrá de tenerse en cuenta el grado de intensidad con el que se impide el tránsito de las personas.

Desde mi punto de vista, el resultado de la ponderación, como regla general, ha de ser favorable al ejercicio del derecho a la libertad de expresión por las personas que ejercen la mendicidad. Con las excepciones de las actitudes auténticamente coactivas o de acoso, los supuestos en que se impida efectivamente el libre tránsito de las personas, y la mendicidad ejercida por menores o con menores. Pero incluyendo actuaciones llevadas a cabo por las personas que ejercen la mendicidad que pueden resultar molestas para las demás personas.

\subsubsection{Derecho a la libertad personal y prohibición de dormir en la calle}

Como ya se ha señalado, según la jurisprudencia y la doctrina mayoritaria, el derecho a la libertad personal del artículo 17 CE no se vería implicado en la regulación que afecta a las actividades cotidianas de las personas sin hogar. Ya señalé mi opinión contraria, teniendo en cuenta la prohibición general de realizar estas actividades que implica para las personas sin hogar. Desde esta premisa paso a analizar la ponderación.

En este caso, los derechos y bienes en conflicto son, por un lado, el derecho a la libertad personal, y por otro, en general «la garantía de un uso racional y ordenado del espacio público y sus elementos»; y cuando corresponda «la salvaguarda de la salubridad, la protección de la seguridad y el patrimonio municipal» ${ }^{104}$.

En cuanto a la importancia de cada uno de ellos en función de las circunstancias del caso, considero que el derecho a la libertad personal se encuentra fuertemente implicado debido a la prohibición general de realizar actividades cotidianas de las personas sin hogar que implican estas ordenanzas. Y del hecho de que los espacios públicos son el único sitio donde las personas sin hogar pueden realizar sus actividades cotidianas ${ }^{105}$.

De esta forma, el contenido del derecho a la libertad de las personas sin hogar se encuentra fuertemente implicado en la prohibición de dormir en la calle, utilizar bancos y asientos públicos para usos distintos,

Y es que es de esencia a la convivencia la general aceptación de innumerables perturbaciones (de la tranquilidad, esto es del sosiego y quietud individuales) que, por su naturaleza, son socialmente considerados irrelevantes...».

99 Según la STC 195/2003, de 27 de octubre, FJ 9, «la prohibición de instalar mesas o una tienda de campaña por los reunidos, con virtualidad para la exposición e intercambio de mensajes e ideas, no puede justificarse en meras dificultades o simples molestias». Se trataba de una concentración manifestación convocada un domingo en una plaza contigua a una basílica en la que se celebran actos religiosos. EI TC sí consideró justificada la prohibición del uso de megafonía durante la celebración de los oficios religiosos (FJ 8).

100 Véase CACHÓN VILLAR, Pablo (2008): 1020.

101 RODRÍGUEZ-PIÑERO Y BRAVO FERRER, Miguel (2008): 1122. Principios que han sido desarrollados en la Ley 51/2003, de 2 de diciembre, de igualdad de oportunidades, no discriminación y accesibilidad universal de las personas con discapacidad.

102 Así lo señala BALAGUER PÉREZ, Amalia (2014), 712, como idea general, no en el marco de un juicio de ponderación.

103 Sobre la no ponderación de los hechos, véase RODRÍGUEZ DE SANTIAGO, José María (2000): 134.

104 En el caso de las prohibiciones relacionadas con las necesidades fisiológicas, se trata de «la protección de la salud pública y la salubridad, el derecho de disfrutar de un espacio público limpio y no degradado, y el respeto a las pautas generalmente aceptadas de convivencia ciudadana y civismo»

105 Aunque se trate de un hecho, no ponderable por tanto, como ya se ha señalado, se puede utilizar para otorgar prevalencia a un derecho frente a otro; RODRÍGUEZ DE SANTIAGO, José María (2000): 134. 
REALA. Nueva Época - N. ${ }^{\circ}$, noviembre 2016 - ISSN: 1989-8975 - DOI: 10.24965/reala.v0i6.10384 - [Págs. 7-26]

Las ordenanzas locales como instrumento de exclusión social: la regulación que afecta a las personas sin hogar es derecho ...

Eduardo Melero Alonso

lavarse o lavar ropa, o realizar las necesidades fisiológicas en lugares públicos. Son actividades urgentes y cotidianas, que las personas tienen que realizar ${ }^{106}$.

En cuanto a la intensidad con la que se encuentran implicadas el uso racional del espacio público, la salubridad, seguridad y protección del patrimonio, dependerá de la manera concreta en que se han realizado las actividades prohibidas. Podría pensarse en un caso en el que una persona duerme en la calle y, por la mañana, recoge sus pertenencias depositando los cartones u otros objetos que ha empleado para dormir en el contenedor de residuos urbanos que corresponda. La afección a uso del espacio público, salubridad,... se habrían visto apenas o nada implicados. Por lo que debería primar el derecho a la libertad personal. En los demás casos habrá que estar a las circunstancias concretas en que se produce. Aunque, como regla general, considero que el resultado de la ponderación debe otorgar prevalencia al derecho a la libertad de las personas sin hogar, debido al importante grado en que este derecho se ve afectado.

\section{LA REGULACIÓN SOBRE LAS PERSONAS SIN HOGAR EN LAS ORDENANZAS LOCALES COMO DERECHO ADMINISTRATIVO DEL ENEMIGO}

En mi opinión, la regulación de las ordenanzas locales en lo que afecta a las personas sin hogar es una medida de exclusión social. En concreto, considero que esta exclusión se está poniendo en práctica a través de la utilización del «derecho administrativo del enemigo». Esta categoría jurídica parte de la doctrina del «derecho penal del enemigo» ${ }^{107}$, elaborada por el penalista alemán Günther JAKOBS, quien distingue derecho penal del ciudadano y derecho penal del enemigo, entendidos ambos como tipos ideales ${ }^{108}$.

Mientras el derecho penal del ciudadano se somete a todas las garantías jurídicas, JAKOBS concibe el derecho penal del enemigo como un instrumento para combatir a aquellos individuos que se consideran peligrosos y que, por tanto, son calificados como enemigos. El ciudadano es la «persona que actúa en fidelidad del ordenamiento jurídico» ${ }^{109}$; el enemigo es aquel que "por principio se conduce de modo desviado» ${ }^{110}$, "quien persistentemente delinque una y otra vez» ${ }^{111}$. La doctrina de JAKOBS permite una interpretación bastante amplia sobre quién se considera enemigo. Desde un punto de vista crítico, se ha afirmado que "el Derecho penal del enemigo no reprime el delito, sino la heterodoxia» ${ }^{112}$.

Según Günther JAKOBS, el derecho penal del enemigo se define por las siguientes «particularidades típicas»: 1) se produce un amplio adelantamiento de la punibilidad, tomándose como referencia un hecho que se va a producir en vez del hecho producido; 2) las penas que se establecen son desproporcionadamente altas; la anticipación de la punibilidad no se tiene en cuenta para reducir la pena en la misma proporción; 3) «paso de la legislación de derecho penal a la legislación de lucha para combatir la delincuencia»; y 4) se suprimen determinadas garantías procesales ${ }^{113}$.

Desde un punto de vista crítico con la doctrina del derecho penal del enemigo, se ha puesto de manifiesto un elemento adicional, que vendría a ser su quinta característica: 5) se identifica a una determinada categoría de sujetos como enemigos, demonizándolos, orientándose la regulación hacia el derecho penal de autor ${ }^{114}$.

En mi opinión, la categoría del «derecho penal del enemigo» puede utilizarse como una herramienta de análisis crítico de determinados sectores del derecho administrativo ${ }^{115}$. Se trataría de un "derecho administrativo del enemigo», vigente en aquellos de actuación administrativa en los que se utiliza el derecho como un instrumento para combatir a aquellos individuos que son considerados como especialmente peligrosos.

Desde el punto de vista metodológico, el «derecho administrativo del enemigo» es también un tipo ideal. Que se define a través de las mismas notas distintivas que caracterizan al derecho penal del enemigo, reformuladas en la medida en que lo exijan las peculiaridades que plantea su utilización en el ámbito del derecho

\footnotetext{
106 WALDRON, Jeremy (1991-1992): 321.

107 Un análisis más amplio del derecho penal del enemigo puede consultarse en MELERO ALONSO, Eduardo (2015): 424 a 427.

108 Véase JAKOBS, Günther (2003): 21, 33 y 42-43.

109 JAKOBS, Günther (2003): 36.

110 JAKOBS, Günther (2003): 55-56.

111 JAKOBS, Günther (2003): 14.

112 GARCÍA AMADO, Juan Antonio (2006): 893.

113 JAKOBS, Günther (2004): 58-59.

114 Véase CANCIO MELIÁ, Manuel y MARAVER GÓMEZ, Mario (2005): 405-406.

115 Así lo ha hecho PRESNO LINERA, Miguel Ángel (2014): 280-288; utilizando la categoría «derecho sancionador del enemigo». Yo también la he empleado en el estudio de las expulsiones en caliente, en MELERO ALONSO, Eduardo (2015): 427-429.
} 
administrativo. Considero que no es necesario que estén presentes las cinco notas distintivas del derecho administrativo del enemigo para poder incluir una determinada regulación dentro de esta categoría ${ }^{116}$.

Una vez delimitada la categoría, vamos a ver en qué medida se encuentran presentes las notas distintivas del derecho administrativo del enemigo en la regulación de las ordenanzas locales que afecta a las personas sin hogar.

1. No se produce un adelantamiento de la punibilidad en las infracciones previstas en las ordenanzas locales en relación con las actividades de las personas sin hogar ${ }^{117}$.

2. En principio, no se trata de sanciones desproporcionadamente altas. La mayoría de infracciones son leves. Sin embargo, en sentido relativo sí puede considerarse que son sanciones especialmente graves si se tiene en cuenta que se está sancionando a personas sin recursos.

3. En muchos de los supuestos nos encontramos ante una legislación que combate frente a las personas sin hogar (con la excepción de la prohibición de la mendicidad llevada a cabo por menores o con menores o de las coacciones). Se ha señalado que algunas de las prohibiciones que contienen las ordenanzas «buscan la desaparición de la pobreza de los centros de las ciudades, algo que es manifiesto además pues estas afectan a las personas sin hogar de manera casi exclusiva, al tratarse de prohibiciones sobre actividades básicas para la vida humana, como dormir o lavarse, que normalmente no son llevadas a cabo en la calle por aquellas personas que disponen de un lugar privado y propio en el que realizarlas» ${ }^{118}$.

Debe destacarse el efecto de conjunto -una especie de efecto sinérgico- que tiene la regulación de las ordenanzas locales en la lucha contra las personas sin hogar, que afectan a sus actividades cotidianas y que necesariamente han de llevar a cabo. La Ordenanza tipo de la FEMP incluye todos los ámbitos de prohibición analizados en este trabajo.

4. También se produce una supresión de las garantías y derechos de las personas sin hogar. En especial de su libertad de expresión. También pude defenderse que se está vulnerando su derecho a la libertad personal, aunque desde la doctrina y la jurisprudencia mayoritarias no sería así.

5. Por último, se produce una clara identificación de una determinada categoría de sujetos. Aunque las ordenanzas son generales y abstractas, se aplican directamente a las personas sin hogar. Como señala Amalia BALAGUER PÉREZ en relación con la prohibición de dormir en la calle: «Resulta sin embargo difícil imaginar que haya muchos casos de personas que duerman en la calle sin encontrarse en exclusión. En este sentido, las leyes y ordenanzas que prohíben dormir en la calle suponen un caso de discriminación indirecta para algunas personas pues, aunque dirigidas a todo el mundo, sólo afectan a parte de la población» ${ }^{119}$. Argumento trasladable al conjunto de la regulación de las personas sin hogar en las ordenanzas locales ${ }^{120}$.

En conclusión, considero que nos encontramos ante un supuesto de derecho administrativo del enemigo. Están presentes, al menos, tres de las cinco notas distintivas de esta categoría. No se trata de uno de los supuestos más graves, como es el de las expulsiones en caliente, pero es derecho administrativo del enemigo.

116 Así lo reconocen, implícitamente para el derecho penal del enemigo, CANCIO MELIÁ, Manuel y MARAVER GÓMEZ, Mario (2005): 407-410, al analizar la pena de expulsión de ciudadanos extranjeros sin residencia legal, establecida en el artículo 89 del Código Penal. A la que incluyen dentro del derecho penal del enemigo a pesar de no concurrir en ella la primera nota distintiva: el adelantamiento de la punibilidad.

117 Aunque sí quiero volver a destacar que las prohibiciones de dormir en la calle, utilizar los bancos públicos de forma inadecuada y la prohibición de rebuscar en la basura no requieren para imponer sanciones que se ensucien los espacios públicos.

En relación con las ordenanzas de convivencia, RUIZ-RICO RUIZ, Catalina (2014): 3, afirma que «EI reverso de la defensa jurídica conferida al derecho constitucional de los demás en la esfera local frente a meras incomodidades implica un adelantamiento de la respuesta legal y de los límites de los derechos fundamentales». Este argumento podría utilizarse para justificar la concurrencia de esta nota distintiva. En mi opinión, más bien se trata de un problema de no reconocimiento de derechos a las personas sin hogar, en el que se encuentra implicada la cuarta nota distintiva del derecho administrativo del enemigo.

118 BALAGUER PÉREZ, Amalia (2014): 713-714. En el mismo sentido, RUIZ-RICO RUIZ: Catalina (2014): 4, señala que «a través de medidas prohibitivas como lavarse con jabón en duchas públicas, se han confeccionado infracciones destinadas a categorías específicas con el fin de desincentivar la presencia de mendigos y excluidos sociales especialmente en las localidades turísticas».

119 BALAGUER PÉREZ, Amalia (2014): 708.

120 Esta identificación es clara en ya citada STSJ Castilla y León, Valladolid, de 8 de octubre de 2013, FJ 10 (JURl2013।330557), según la cual «La mera petición de dinero, de tabaco, de transporte... etc., hecha por un no indigente, no es tal acción de mendigar». Por tanto, la regulación sobre mendicidad sólo se aplicaría a las personas indigentes. 
REALA. Nueva Época - N. ${ }^{6}$, noviembre 2016 - ISSN: 1989-8975 - DOI: 10.24965/reala.v0i6.10384 - [Págs. 7-26]

Las ordenanzas locales como instrumento de exclusión social: la regulación que afecta a las personas sin hogar es derecho ...

Eduardo Melero Alonso

\section{CONCLUSIONES Y PERSPECTIVAS}

Las ordenanzas de convivencia de Barcelona y de la Federación Española de Municipios y Provincias tratan a las personas sin hogar como personas sin derechos. Asumen así la distinción fundamental propia del derecho penal del enemigo: la contraposición entre personas e individuos sin derechos. Se puede considerar esta regulación como derecho administrativo del enemigo, ya que concurren sus notas distintivas más importantes, aunque no se trate de uno de los casos más graves, como las expulsiones en caliente.

Se trata de una normativa que castiga las actividades cotidianas de las personas sin hogar. De esta forma se está poniendo en práctica una política de exclusión social.

Hay quien ha relacionado el derecho penal del enemigo con el derecho de excepción ${ }^{121}$. No tengo tan claro que suceda lo mismo con el derecho administrativo del enemigo. En un trabajo anterior sobre las expulsiones en caliente lo situé en una posición intermedia entre el derecho aplicable en situaciones de normalidad y el derecho de excepción, encuadrándolo dentro de la categoría "estado de excepción atenuado personalizado» ${ }^{122}$. Ahora tiendo a pensar que el derecho administrativo del enemigo es un derecho que regula situaciones de normalidad. Un derecho que se sitúa en línea con las dinámicas de expulsión social prevalentes desde los años 80, en las que el funcionamiento normal de la economía y la sociedad expulsa a personas de dichos ámbitos ${ }^{123}$. Una dinámica que puede significar que la excepción se ha convertido en la nueva normalidad ${ }^{124}$.

\section{BIBLIOGRAFÍA CITADA}

ARROYO JIMÉNEZ, Luis (2009): «Ponderación, proporcionalidad y Derecho administrativo», en ORTEGA, Luis y DE LA SIERRA, Susana (coords.): Ponderación y Derecho administrativo, Marcial Pons, Madrid, págs. 19 a 49.

BALAGUER PÉREZ, Amalia (2014): «La criminalización de las personas sin hogar», en BALAGUER CALLEJÓN, Francisco y ARANA GARCÍA, Estanislao (coords.): Libro Homenaje al Profesor Rafael Blanco Vela. Volumen I, Civitas, Cizur Menor, págs. 695 a 716.

BARNÉS, Javier (1998): «El principio de proporcionalidad. Estudio preliminar», Cuadernos de Derecho Público, núm. 5 (septiembre-diciembre 1998), págs. 15 a 49.

BASTIDA FREIJEDO, Francisco J. (2011): «Libertad de circulación», en ARAGÓN REYES, Manuel (dir.): Derechos fundamentales y su protección. Temas básicos de Derecho Constitucional. Tomo III, Civitas, Madrid, págs. 166 a 168.

CACHÓN VILLAR, Pablo (2008): «Artículo 39», en CASAS BAAMONDE, María Emilia y RODRÍGUEZ-PIÑERO Y BRAVO-FERRER, Miguel (dirs.): Comentarios a la Constitución Española. XXX aniversario, Fundación Wolters Kluwer, Las Rozas, págs. 1003 a 1023.

CAPELLA, Juan Ramón (1996): «Un estado de excepción personalizado», en Grandes esperanzas. Ensayos de análisis político, Trotta, Madrid, págs. 40 a 43.

CANCIO MELIÁ, Manuel y MARAVER GÓMEZ, Mario (2005): «El Derecho penal español ante la inmigración: un estudio político-criminal», en BACIGALUPO, Silvina y CANCIO MELIÁ, Manuel (coords.): Derecho penal y política transnacional, Atelier, Barcelona, págs. 343 a 415.

CASINO RUBIO, Miguel (2011): "Las nuevas y discutibles ordenanzas municipales de convivencia», Istituzioni del federalismo. Rivista di studi giuridici e politici, núm. 4, 2011, págs. 743 a 771.

CASINO RUBIO, Miguel (2012): «Ordenanzas de convivencia, orden público y competencia municipal», Justicia Administrativa, núm. $56\left(2 .^{\circ}\right.$ trimestre 2012), págs. 7 a 21.

CASTIÑEIRA PALOU, M. ${ }^{a}$ Teresa y MONTANER FERNÁNDEZ, Raquel (2015): «Tema 9. Delitos contra las relaciones familiares», en SILVA SÁNCHEZ, Jesús María (dir.): Lecciones de Derecho penal. Parte especial, Atelier, Barcelona, págs. 201 a 223.

DÍEZ PICAZO, Luis María (2008): Sistema de derechos fundamentales, Civitas, Cizur Menor.

GARCÍA AMADO, Juan Antonio (2006): «El obediente, el enemigo, el Derecho penal y Jakobs», en CANCIO MELIÁ, Manuel y GÓMEZ-JARA DÍEZ, Carlos (coords.): Derecho penal del enemigo. El discurso penal de la exclusión, Volumen 1, Edisofer - Euros Editores, Buenos Aires, 2006, págs. 887 a 924.

GARCÍA TORRES, Jesús y REQUEJO PAGÉS, Juan Luis (2011): «Libertad y seguridad personales», en ARAGÓN REYES, Manuel (dir.): Derechos fundamentales y su protección. Temas básicos de Derecho Constitucional. Tomo III, Civitas, Madrid, págs. 158 a 166.

121 PRIETO NAVARRO, Evaristo (2008): 134; señalando su vinculación con el pensamiento de Carl Schmitt (véase págs. 130-131).

122 MELERO ALONSO, Eduardo (2015): 430. Según CAPELLA, Juan Ramón: (1996): 42, el estado de excepción atenuado

personalizado implica «que ciertos derechos y libertades, válidos en general, pueden ser retirados temporalmente por el poder gubernativo».

${ }^{123}$ Sobre estas dinámicas de expulsión en la economía y la sociedad, véase SASSEN, Saskia (2015): 91 y 237.

124 La «normalización de lo excepcional» es apuntada por PRIETO NAVARRO, Evaristo (2008): 80 y 114. 
REALA. Nueva Época - N. 6, noviembre 2016 - ISSN: 1989-8975 - DOI: 10.24965/reala.v0i6.10384 - [Págs. 7-26]

Las ordenanzas locales como instrumento de exclusión social: la regulación que afecta a las personas sin hogar es derecho ..

Eduardo Melero Alonso

JAKOBS, Günther (2003): «Derecho penal del ciudadano y Derecho penal del enemigo», en JAKOBS, Günther y CANCIO MELIÁ, Manuel: Derecho penal del enemigo, Civitas, Madrid, págs. 21 a 56.

JAKOBS, Günther (2004): «La autocomprensión de la ciencia del Derecho penal ante los desafíos del presente (Comentario)», en ESER, Albin, HASSEMER, Winfried y BURKHARDT, Björn (coords.): La ciencia del Derecho penal ante el Nuevo milenio, Tirant lo Blanch, Valencia, 2004, págs. 53 a 64.

JIMÉNEZ CAMPO, Javier (2008): «Artículo 10.1», en CASAS BAAMONDE, María Emilia y RODRÍGUEZ-PIÑERO Y BRAVO-FERRER, Miguel (dirs.): Comentarios a la Constitución Española. XXX aniversario, Fundación Wolters Kluwer, Las Rozas, págs. 178 a 192.

LASCURAÍN SÁNCHEZ, Juan Antonio (2008): «Artículo 17.1. El derecho a la libertad», en CASAS BAAMONDE, María Emilia y RODRÍGUEZ-PIÑERO Y BRAVO-FERRER, Miguel (dirs.): Comentarios a la Constitución Española. XXX aniversario, Fundación Wolters Kluwer, Las Rozas, págs. 366 a 377.

LOSADA GONZÁLEZ, Herminio (2008): «Artículo 19», en CASAS BAAMONDE, María Emilia y RODRÍGUEZ-PIÑERO Y BRAVO-FERRER, Miguel (dirs.): Comentarios a la Constitución Española. XXX aniversario, Fundación Wolters Kluwer, Las Rozas, págs. 460 a 469.

MELERO ALONSO, Eduardo (2015): «El retorno en frontera en Ceuta y Melilla (o las "expulsiones en caliente"): un supuesto de derecho administrativo del enemigo», Revista Española de derecho Administrativo, núm. 174 (octubre-diciembre 2015), págs. 401 a 433.

MERINO ESTRADA, Valentín (2006): "Las nuevas Ordenanzas municipales reguladoras de la convivencia ciudadana», Revista de Estudios de la Administración Local y Autonómica, núm. 300-301 (enero-agosto 2006), págs. 485 a 510.

MUÑOZ CONDE, Francisco (2015): Derecho Penal. Parte Especial, Tirant lo Blanch, Valencia.

ORDUÑA PRADA, Enrique (2016): Ordenanzas municipales de convivencia ciudadana, sanciones y democracia local, Centro de Estudios Políticos y Constitucionales, Madrid.

ORTEGA BERNARDO, Julia (2014): Derechos fundamentales y ordenanzas locales, Marcial Pons, Madrid.

PEMÁN GAVÍN, Juan M. ${ }^{\text {a }}$ (2007): «Ordenanzas municipales y convivencia ciudadana. Reflexiones a propósito de la Ordenanza de civismo de Barcelona», Revista de Estudios de la Administración Local y Autonómica, núm. 305 (septiembre-diciembre 2007), págs. 9 a 55.

PEMÁN GAVÍN, Juan M. ${ }^{a}$ (2010): «La política de civismo en los ayuntamientos españoles. Entre policía, acción social y educación cívica», Revista Aragonesa de Administración Pública, núm. 36, junio 2010, págs. 11 a 51.

PONCE SOLÉ, Juli y FERNÁNDEZ EVANGELISTA, Guillem (2010): «Derecho urbanístico, derecho a la vivienda y personas sin hogar. Nuevos desarrollos y perspectivas en España a la vista de las novedades europeas en la materia», Revista de Derecho Urbanístico y Medio Ambiente, núm. 255 (enero-febrero 2010), págs. 39 a 78.

POTS, Cory y MARTIN, Lucie (2013): «Penal Visions of Homelessness and Responsabilisation in Belgium», en FERNÀNDEZ EVANGELISTA, Guillem (coord.): Mean streets. A report on the criminalization of homelessness in Europe, Belgium, págs. 77 a 89.

PRESNO LINERA, Miguel Ángel (2014): «El primer Anteproyecto de Ley Orgánica para la Protección de la Seguridad Ciudadana», Teoría y Realidad Constitucional, núm. 34, págs. 269 a 292.

PRIETO NAVARRO, Evaristo (2008): «Excepción y normalidad como categorías de lo político», en CANCIO MELIÁ, Manuel y Pozuelo Pérez, Laura (coords.): Política criminal en vanguardia. Inmigración clandestina, terrorismo, criminalidad organizada, Civitas, Cizur Menor, págs. 77 a 136.

RAGUÉS I VALLĖS, Ramon (2015): «Tema 4. Delitos contra la libertad», en SILVA SÁNCHEZ, Jesús María (dir.): Lecciones de Derecho penal. Parte especial, Atelier, Barcelona, págs. 95 a 114.

REBOLLO PUIG, Manuel e Izquierdo Carrasco, Manuel (2007): «Artículo 84», en REBOLLO PUIG, Manuel (Dir.): Comentarios a la Ley Reguladora de las Bases del Régimen Local. Tomo II, Tirant lo Blanch, Valencia, págs. 2155 a 2255.

REY, FERNANDO (2013): "Lección 16. Los derechos clásicos de libertad», en VVAA: Lecciones de Derecho constitucional II, Lex Nova, Pamplona, págs. 501 a 541.

RODRÍGUEZ-PIÑERO Y BRAVO FERRER, Miguel (2008): "Artículo 49», en CASAS BAAMONDE, María Emilia y RODRÍGUEZ-PIÑERO Y BRAVO-FERRER, Miguel (dirs.): Comentarios a la Constitución Española. XXX aniversario, Fundación Wolters Kluwer, Las Rozas, págs. 1118 a 1123.

RODRÍGUEZ DE SANTIAGO, José María (2000): La ponderación de bienes e intereses en el Derecho administrativo; Marcial Pons, Madrid.

RUIZ-RICO RUIZ, Catalina (2014): «Las Ordenanzas Locales de Convivencia y su impacto constitucional (a propósito de la STS de 14 de febrero de 2013)», Actualidad Administrativa, núm. 1 (enero 2014), se cita según la versión digital de La Ley - Biblioteca digital - Smarteca.

SASSEN, Saskia (2015): Expulsiones. Brutalidad y complejidad en la economía global, Katz, Móstoles.

SOLOZÁBAL ECHAVARRÍA, Juan José (2011): «Libertad de expresión y derecho a la información», en ARAGÓN REYES, Manuel (dir.): Derechos fundamentales y su protección. Temas básicos de Derecho Constitucional. Tomo III, Civitas, Madrid, págs. 197 a 205.

VELASCO CABALLERO, Francisco (2009): Derecho local. Sistema de fuentes, Marcial Pons, Madrid.

VILLAVERDE MENÉNDEZ, Ignacio (2008): «Artículo 20.1.a) y d), 20.2, 20.4 y 20.5. La libertad de expresión», en CASAS BAAMONDE, María Emilia y RODRÍGUEZ-PIÑERO Y BRAVO-FERRER, Miguel (dirs.): Comentarios a la Constitución Española. XXX aniversario, Fundación Wolters Kluwer, Las Rozas, págs. 472 a 502.

WALDRON, Jeremy (1991-1992): «Homelessness and the issue of freedom», UCLA Law Review, Vol. 39, págs. 295 a 324. 